University of Nebraska - Lincoln

DigitalCommons@University of Nebraska - Lincoln

\title{
Biosynthesis of HSAF, a Tetramic Acid-containing Macrolactam from Lysobacter enzymogenes
}

\author{
Lili Lou \\ University of Nebraska-Lincoln \\ Guoliang Qian \\ Nanjing Agricultural University \\ Yunxuan Xie \\ University of Nebraska-Lincoln \\ Jiliang Hang \\ University of Nebraska-Lincoln \\ Haotong Chen \\ University of Nebraska-Lincoln
}

See next page for additional authors

Follow this and additional works at: https://digitalcommons.unl.edu/chemistrydussault

Lou, Lili; Qian, Guoliang; Xie, Yunxuan; Hang, Jiliang; Chen, Haotong; Zaleta- Rivera, Kathia; Li, Yaoyao; Shen, Yuemao; Dussault, Patrick; Liu, Fengquan; and Du, Liangcheng, "Biosynthesis of HSAF, a Tetramic Acid-containing Macrolactam from Lysobacter enzymogenes" (2011). Patrick Dussault Publications. 25. https://digitalcommons.unl.edu/chemistrydussault/25

This Article is brought to you for free and open access by the Published Research - Department of Chemistry at DigitalCommons@University of Nebraska - Lincoln. It has been accepted for inclusion in Patrick Dussault Publications by an authorized administrator of DigitalCommons@University of Nebraska - Lincoln. 


\section{Authors}

Lili Lou, Guoliang Qian, Yunxuan Xie, Jiliang Hang, Haotong Chen, Kathia Zaleta- Rivera, Yaoyao Li, Yuemao Shen, Patrick Dussault, Fengquan Liu, and Liangcheng Du 


\title{
Author Manuscript
}

\section{Published in final edited form as:}

J Am Chem Soc. 2011 February 2; 133(4): 643-645. doi:10.1021/ja105732c.

Copyright $\odot 2010$ American Chemical Society

\section{Biosynthesis of HSAF, a Tetramic Acid-containing Macrolactam from Lysobacter enzymogenes}

\author{
Lili Lou ${ }^{\dagger}$, Guoliang Qian $\ddagger$, Yunxuan Xie ${ }^{\dagger}$, Jiliang Hang ${ }^{\dagger}$, Haotong Chen ${ }^{\dagger}$, Kathia Zaleta- \\ Rivera ${ }^{\dagger}$, Yaoyao $\mathrm{Li}^{\dagger}$, Yuemao Shen, Patrick H Dussault ${ }^{\dagger}$, Fengquan Liu ${ }^{\ddagger}$, and Liangcheng \\ Dut \\ Department of Chemistry, University of Nebraska-Lincoln, Lincoln, NE 68588, Department of \\ Plant Pathology, Nanjing Agricultural University, Nanjing 210095, China, and State Key \\ Laboratory of Microbial Technology, School of Life Science, Shandong University, Jinan 250100, \\ China
}

\section{Abstract}

HSAF was isolated from Lysobacter enzymogenes, a bacterium used in the biological control of fungal diseases of plants. Structurally, it is a tetramic acid-containing macrolactam fused to a tricyclic system. HSAF exhibits a novel mode of action by disrupting sphingolipids important to the polarized growth of filamentous fungi. Here, we described the HSAF biosynthetic gene cluster which contains only a single-module polyketide synthase-nonribosomal peptide synthetase (PKS/ NRPS), although the biosynthesis of HSAF apparently requires two separate polyketide chains that are linked together by one amino acid (ornithine) via two amide bonds. Flanking the PKS/ NRPS are six genes, encoding a cascade of four tightly clustered redox enzymes on one side and a sterol desaturase/fatty acid hydroxylase and a ferredoxin reductase on the other side. The genetic data demonstrate that the four redox genes, in addition to the PKS/NRPS gene and the sterol desaturase/fatty acid hydroxylase gene, are required for HSAF production. The biochemical data show that the adenylation domain of the NRPS specifically activated L-ornithine and the fourdomain NRPS was able to catalyze the formation of a tetramic acid-containing product from acyl$S$-ACP and ornithinyl-S-NRPS. These results reveal a previously unrecognized biosynthetic mechanism for hybrid PK/NRP in prokaryotic organisms.

We have previously isolated a novel antifungal compound (HSAF, 1) from Lysobacter enzymogenes $\mathrm{C} 3$, which is a bacterium used for the biological control of fungal diseases of plants. ${ }^{1} \mathrm{HSAF}$ exhibits potent inhibitory activities against a wide range of fungal species and shows a novel mode of action by disrupting the biosynthesis of fungal sphingolipids. ${ }^{2}$ Sphingolipids represent an attractive new target for the development of novel antifungal drugs because their structure in fungal cells is distinct from that in mammalian cells. ${ }^{3} \mathrm{HSAF}$ is a tetramic acid (2,4-pyrrolidinedione)-containing macrolactam (Figure 1). ${ }^{1}$ Tetramic acid is the key structural feature for many bioactive heterocycles that exhibit a wide range of biological activities including antibiotic and anticancer activities. ${ }^{4}$ The macrolactam structure is also found in many bioactive natural products. HSAF combines these two structural features. In addition, it contains a 5,5,6-tricyclic system fused to the macrolactam. Such structural features are shared by a group of natural products (2-7) that were isolated

\footnotetext{
ldu@unlserve.unl.edu; fqliu20011@ sina.com.

$\dagger$ University of Nebraska-Lincoln

*Nanjing Agricultural University; Shandong University; LL and GLQ are joint first authors.

Supporting Information Available: Details of experimental procedures, HSAF gene cluster annotation, gene disruption/deletion, chemical synthesis, and protein expression and activity assays. This material is available free of charge via the Internet at http://pubs.acs.org.
} 
from marine invertebrates and/or associated microorganisms (Figure 1). No biosynthetic studies on these marine metabolites have been reported. Previously, we reported four HSAF biosynthetic genes, including a hybrid polyketide synthase-nonribosomal peptide synthetase (PKS/NRPS). Since then, we have been searching for additional PKS genes around this PKS/NRPS locus, because the biosynthesis of HSAF apparently requires two separate polyketide chains. We now provide the complete sequence of the gene cluster based on the genome sequences. The most striking finding is that only a single PKS/NRPS is present in the gene cluster. We have also expressed the NRPS module and demonstrated in vitro that it specifically activates L-ornithine and catalyzes the formation of a tetramate product.

In L. enzymogenes C3, we previously identified three genes downstream to the PKS/NRPS. Gene disruption data showed that only the gene encoding sterol desaturase/fatty acid hydroxylase is required for HSAF production. ${ }^{1}$ Because biosynthetic genes for PK/NRP in microorganisms are almost always clustered together, we searched the region upstream to the PKS/NRPS, where we found four genes (OX1 to OX4, EF028635.2) that encode a cascade of NADP/FAD-dependent oxidoreductases. OX1, 2, and 3 are similar to each other, while OX4 is distinct (Figure 1). The OX genes appear to form an operon with the PKS/ NRPS, because they are either translationally coupled or have only a small intergenic region in between. To test their relevance to HSAF biosynthesis, we disrupted each of the OX genes. The disruption mutants of OX1, 2, and 3 did not produce HSAF, whereas the disruption mutants of OX4 produced a small amount of a metabolite with a $[\mathrm{M}+\mathrm{H}]^{+}$of 511.2789, which is two mass units smaller than HSAF and coincident with the mass of maltophilin, a putative precursor of HSAF (Figure S1). To eliminate the potential polar effect caused by insertion of the conjugal vector, we then generated four in-frame deletion mutants by deleting a small sequence (6-11 residues) at the highly conserved active sites of the OXs (Figure S2-S5). The results showed that the deletion mutants of OX1, 2, and 3 did not produce HSAF while the OX4 deletion mutants still produced the same putative precursor. Together, the results show that the OX genes are required for the biosynthesis of the final product.

The Liu group has been using L. enzymogenes $\mathrm{OH} 11$ as a biocontrol agent for plant fungal diseases in China. ${ }^{5} \mathrm{We}$ recently completed the draft genome sequence of strain $\mathrm{OH} 11$. The results showed that strain $\mathrm{OH} 11$ has all the HSAF genes found in strain $\mathrm{C} 3$. Within the HSAF genes (20280 bp), the two strains have a $96 \%$ identity. At the amino acid sequence level, the individual ORFs have an identity of $98-99 \%$. With the genome sequence, we could search for "extra PKS" genes juxtaposed to the HSAF locus. Surprisingly, no such gene is present. The center of the gene cluster is the hybrid PKS/NRPS. Flanking the PKS/NRPS are genes encoding six redox enzymes, arginase, putative transporters and receptors/ regulators (Figure 1B and S6). Beyond the $55 \mathrm{~kb}$ region shown in Figure 1B, we only found genes encoding rRNA, ribosome proteins, tRNA and DNA repairing proteins, which apparently are not related to HSAF biosynthesis. The HSAF biosynthetic gene cluster contains only a single-module PKS/NRPS, a cascade of redox enzymes, and several putative transporter/regulators. Recently, Clardy and coworkers also observed similar results in gene clusters mined from a number of Streptomyces genomes. ${ }^{6}$ They found that this type of single-module hybrid PKS/NRPS is conserved among phylogenetically diverse bacterial species.

To test whether the single NRPS module could accept two separate acyl chains to produce the characteristic tetramic acid-containing product, we conducted a series of in vitro experiments. We first expressed the adenylation domain of the PKS-NRPS in E. coli and used the purified $66.4 \mathrm{kDa}$ protein (Figure S7) for an ATP-PPi exchange assay. Among the 16 amino acids tested, the A-domain specifically activates L-ornithine and, to a lesser extent, L-lysine (Figure S7). We then tested the in vitro activity of the entire NRPS module 
(Figure 2). The 4-domain NRPS (C-A-PCP-TE) was expressed in E. coli as a His 6 -tagged protein with an expected size of $148.6 \mathrm{kDa}$ (Figure 2B). The promiscuous 4'-

phosphopantetheine transferase Svp was used to prepare stearoyl-S-ACP and holo-NRPS. ${ }^{7}$ The holo-NRPS was then loaded with L-ornithine in the presence of ATP, producing the ornithinyl-SNRPS substrate (Figure 2A). When stearoyl-S-ACP and ornithinyl-S-NRPS were incubated together, we detected a $[\mathrm{M}+\mathrm{H}]^{+}$ion of 647.6080 in the reactions (Figure $2 \mathrm{C}$ ), which is consistent with the predicted mass of the product $\mathbf{8}$. This molecular ion was not present in the control reaction without the NRPS protein. The putative tetramic acid structure was correlated with an authentic sample prepared as illustrated in Scheme 1 (also see Scheme SI-1). The boroxazolidinone adduct of $L$-ornithine (9) was selectively acylated at the terminal amino group with octadecanoyl chloride to furnish a monoamide. ${ }^{8}$

Deprotection of the boroxazolidinone with ethylenediamine, followed by reaction with thionyl chloride in methanol furnished methyl ester 10. Conversion of the amino acid ester to the tetramic acid was accomplished through a modification of a published approach. ${ }^{9}$ Condensation of the amino ester with 2-benzyloxycarbonyloctacadecanoic acid 11, prepared in two steps from dibenzyl malonate, furnished the $\alpha, \delta$-bisamide $\mathbf{1 2}$ as an inseparable $\sim 1: 1$ mixture of diastereomers. Reaction with excess sodium hydride resulted in tandem Claisen condensation and deacylation to furnish tetramic acid $\mathbf{8}$ as a 1:1 mixture of epimers at $C_{3}$ of the 3,5-dioxopyrrolidine. The retention time and mass spectra of the synthetic tetramic acid sample matched exactly the enzymatically synthesized material (Figure 2C).

These results show that the two amide functionalities in HSAF are formed between two acyl chains and ornithine, one at the $\alpha$-amino and the other at the $\delta$-amino group of ornithine. The results also suggest that the HSAF NRPS module is able to accept two polyketide acyl-SACPs, making two amide bonds on the same amino acid via two Claisen-condensation reactions and forming the tetramic acid ring via a Dieckmann-type reaction.

Hybrid PKS/NRPS have been found in gene clusters for several tetramic acid-containing natural products, such as tenellin, aspyridone A, equisetin, and cyclopiazonic acid. ${ }^{10}$ All these PKS/NRPS contain a reductase (R) domain in the end of the enzyme, which is responsible for the cyclization of tetramic acid and the release of the hybrid PK/NRP chain via a Dieckmann-type condensation. In HSAF PKS/NRPS, the TE domain is most likely the candidate for this activity. In spite of the functional similarity, the R domain's substrate is a thioester attached to the PCP domain, whereas the TE domain's substrate is an oxoester attached to TE itself. ${ }^{11}$ Another interesting question in HSAF biosynthesis is if the $\mathrm{C}$ domain catalyzes the formation of both amide bonds or if the TE domain is also involved. We are currently working on the enzymes to answer this question.

Clardy and coworkers found that all HSAF-type gene clusters contain a central PKS/NRPS flanked by genes encoding a cascade of redox enzymes. ${ }^{6}$ In HSAF, we found that all four OX genes, in addition to the genes for PKS/NRPS and sterol desaturase/fatty acid hydroxylase, are required for HSAF biosynthesis. These genes could be involved in the formation of the 5,5,6-tricyclic system and the conversion of maltophilin to HSAF. Although the disruption of the ferredoxin reductase gene and arginase gene did not eliminate HSAF production in the mutants, these genes may play a pathway-specific role (as a reducing partner for the redox enzymes, or the synthesis of ornithine from arginine via the urea cycle). The MFS transporter and the TonB-dependent outer membrane receptor could play a role in resistance and regulation.

The iterative use of a single-module PKS/NRPS is common in fungi but is rare in bacteria. ${ }^{12}$ Only a few bacterial modular PKSs were reported to act iteratively. ${ }^{13}$ Here, our results show that HSAF PKS/NRPS presents one of the first two examples where a single-module PKS assembles two separate polyketide chains that are linked together via two amide bonds on 
the same amino acid and are subsequently folded/cyclized into a complex scaffold, probably by a cascade of redox enzymes. These results open a new area of biosynthetic research to study hybrid PK/NRP products with a very unusual scaffold and interesting biological activities.

\section{Supplementary Material}

Refer to Web version on PubMed Central for supplementary material.

\section{Acknowledgments}

This work was supported in part by the NIH (AI073510), Nebraska Research Initiatives, NSFC (31028019), and National High Technology Research and Development Program of China (2006AA10A211). We thank Ron Cerny, Kurt Wulser and Wei Zhang for technical assistance. The research was performed in facilities renovated with support from the NIH (RR015468-01).

\section{References}

1. Yu F, Zaleta-Rivera K, Zhu X, Huffman J, Millet JC, Harris SD, Yuen G, Li XC, Du L. Antimicrob Agents Chemother. 2007; 51:64-72. [PubMed: 17074795]

2. Li S, Du L, Yuen G, Harris SD. Mol Biol Cell. 2006; 17:1218-1227. [PubMed: 16394102]

3. Thevissen K, Francois IE, Aerts AM, Cammue BP. Curr Drug Targets. 2005; 6:923-928. [PubMed: 16375675]

4. Schobert R, Schlenk A. Bioorg Med Chem. 2008; 16:4203-4221. [PubMed: 18334299]

5. Qian GL, Hu BS, Jiang YH, Liu FQ. Agricultural Sciences in China. 2009; 8:68-75.

6. Blodgett JAV, Oh DC, Cao S, Currier CR, Kolter R, Clardy J. PNAS. 2010; 107:11692-11697. [PubMed: 20547882]

7. Sanchez C, Du L, Edwards DJ, Toney MD, Shen B. Chem Biol. 2001; 8:725-738. [PubMed: 11451672]

8. Dent WH, Erickson WR, Fields SC, Parker MH, Tromiczak EG. Org Lett. 2002; 4:1249-1251. [PubMed: 11950334]

9. Page PCB, Hamzah AS, Leach DC, Allin SM, Andrews DM, Rassias GA. Org Lett. 2003; 5:353355. [PubMed: 12556190]

10. a Halo LM, Marshall JW, Yakasai AA, Song Z, Butts CP, Crump MP, Heneghan M, Bailey AM, Simpson TJ, Lazarus CM, Cox RJ. Chembiochem. 2008; 9:585-594. [PubMed: 18266306] b Bergmann S, Schumann J, Scherlach K, Lange C, Brakhage AA, Hertweck C. Nat Chem Biol. 2007; 3:213-217. [PubMed: 17369821] c Sims JW, Schmidt EW. J Am Chem Soc. 2008; 130:11149-11155. [PubMed: 18652469] d Liu X, Walsh CT. Biochemistry-Us. 2009; 48:87468757.

11. Du L, Lou L. Nat Prod Rep. 2010; 27:255-278. [PubMed: 20111804]

12. Cox RJ. Org Biomol Chem. 2007; 5:2010-2026. [PubMed: 17581644]

13. a Shao L, Qu XD, Jia XY, Zhao QF, Tian ZH, Wang M, Tang GL, Liu W. Biochem Biophys Res Commun. 2006; 345:133-139. [PubMed: 16677607] b Wenzel SC, Gross F, Zhang Y, Fu J, Stewart AF, Muller R. Chem Biol. 2005; 12:349-356. [PubMed: 15797219] 


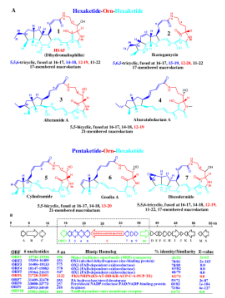

Figure 1.

(A) Structure of HSAF and related tetramic acid-containing macrolactams. The compounds are divided into two groups based on their possible biosynthetic mechanisms: the hexaketide-ornithine-hexaketide group and the pentaketide-ornithine-hexaketide group. Both groups can have a 17-membered macrolactam fused to a tricyclic system or a 21-membered macrolactam fused to a bicyclic system. (B) Map of the HSAF gene cluster (EF028635.2). The ORFs in the blocked region are annotated here; the annotation of the rest of the ORFs is included in Figure S6. 


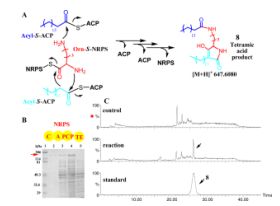

Figure 2.

In vitro synthesis of a tetramic acid-containing product (8) using the purified HSAF NRPS. (A) Schematic illustration of the reactions. The acyl-S-ACP substrate was prepared by incubating ACP and stearoyl-CoA with Svp, and Orn-S-NRPS was prepared by incubating NRPS and CoA with Svp, followed by addition of L-ornithine and ATP. (B) SDS-PAGE showing the expression and purification of the 4-domain NRPS. The expected size of the NRPS is $148.6 \mathrm{kDa}$. Lane-1, markers; lane-2, purified NRPS; lane-3, soluble fraction of protein extracts; lane-4, total protein extracts upon IPTG induction; lane-5, total protein extracts before IPTG induction. (C) LC-MS detection of the expected product 8 . The first is a control reaction without the NRPS, the second is a complete reaction to show the production of the expected product with a $[\mathrm{M}+\mathrm{H}]^{+}$of 647.6080 , and the third is the chemically synthesized standard $\mathbf{8}$ (mixture of diastereomers). 


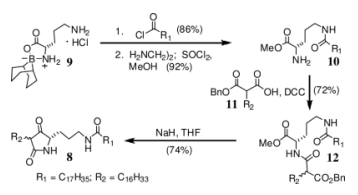

Scheme 1.

Preparation of tetramic acid $\mathbf{8}$. 


\section{Supporting Information (Part 1 of 2)}

\section{Biosynthesis of HSAF, a Tetramic Acid-containing Macrolactam from \\ Lysobacter enzymogenes}

Lili Lou, Guoliang Qian, Yunxuan Xie, Jiliang Hang, Haotong Chen, Kathia Zaleta-Rivera, Yaoyao Li, Yuemao Shen, Patrick H Dussault, Fengquan Liu and Liangcheng Du

\section{$\underline{\text { Outline }}$}

1. General Materials and Methods

2. Generation of four OX gene disruption mutants

p1-5

3. Generation of four OX gene in-frame deletion mutants

4. Mapping of the HSAF locus

p14-15

5. Adenylation domain expression and ATP-PPi exchange assays

6. Whole NRPS module expression

p17-18

7. In vitro assay for the activity of the NRPS module p18-19

8. Chemical synthesis of tetramic acid $\mathbf{8}$ p19-26

9. Reference

p26-27 


\section{General Materials and Methods}

Chemicals used in this study were purchased from Fisher Scientific or Sigma. All

oligonucleotide primers for PCR were synthesized by Integrated DNA Technologies (IDT, Coralville, IA). Plasmid preparation and DNA extraction were carried out with Qiagen kits (Valencia, CA), and all other DNA manipulations were carried out according to standard methods. Escherichia coli strain XL Blue was used as the host for general plasmid DNA propagation, and the cloning vector was pANT841. Vectors pET28a or pQE60 were used for protein expression in E. coli BL21 (DE3) or SG13009 (pREP4), respectively.

\section{Generation of four OX gene disruption mutants}

To construct the gene disruption vectors, an internal fragment was amplified from each of the four OX genes using the primer pairs listed below.

OX1For 5'-GCC GCT GGA GAA CTG GAA GG-3'

OX1Rev 5'-GCTGAA GTA GGT GAC GTG GAT GA-3'

OX2For 5'-GCT GTA CCC GTT CCT GAC GC-3'

OX2Rev 5'-TTC TTC CTC GCT GAG CAG ATA AGT-3'

OX3For 5'-TCC CGG TGC TGC CGT TCT A-3'

OX3Rev 5'-TGC GGT TCG GCG ATG GT-3'

OX4For 5'-AAG CTC GAC CTG CGC CAC T-3'

OX4Rev 5'-TTC TGC TCG GTG AAC CAC TCC-3' 
The sizes of the PCR fragments for OX1, 2, 3, and 4 were 712, 622, 328 and $539 \mathrm{bp}$, respectively. The fragments were cloned into pGEM-T vector and their identity was confirmed by DNA sequencing. Each of the fragments was then transferred to the conjugal vector pJQ200SK as an ApaI/SpeI fragment to produce pJQ200SK-OX1-4. Each of the pJQ200SK-OX was transformed into E. coli S17-1, which was mated with Lysobacter enzymogenes $\mathrm{C} 3$ for conjugal transfer of the constructs. The positive colonies grown on LB plates containing gentamicin $(20 \mu \mathrm{g} / \mathrm{ml})$ were picked up and inoculated into liquid cultures containing gentamicin. Genomic DNA was prepared from each of the cultures, and diagnostic PCR were performed to identify mutants that resulted from a homologous recombination at the respective OX genes. The following primer pairs were used for these experiments.

MOX1For 5'-GGG CAA CAA CGC CAA CC-3'

MOX1Rev 5'-CCC TCA TCA GTG CCA ACA TAG-3'

MOX2For 5'-CTG CAT CGA ATG GCT GAT C-3'

MOX2Rev 5'-TCT TTA TAG TCC TGT CGG GTT T-3'

MOX3For 5'-CCC CTA CTT CAA CGC CAT CC-3'

MOX3Rev 5'-CAC CCT CAT CAG TGC CAA C-3'

MOX4For 5'-ACC TTC CCG ATG GTG TTCC C-3'

MOX4Rev 5'-ACG ACC GAG CGT AGC GAG T-3'

In each of the primer pairs, the forward primer will anneal to the corresponding OX gene at a location that is outside the PCR fragment used in the gene disruption constructs, and the reverse primer will anneal to a location within pJQ200SK vector. The expected size of the PCR product from OX1 mutants was 1345 bp, which will release two fragments of 1000 and 345 bp upon ApaI digestion. The expected size of the PCR product from OX2 mutants was $1566 \mathrm{bp}$, which 
will release two fragments of 916 and 650 bp upon ApaI digestion. The expected size of the PCR product from OX3 mutants was $839 \mathrm{bp}$, which will release two fragments of 492 and $347 \mathrm{bp}$ upon ApaI digestion. The expected size of the PCR product from OX4 mutants was $1072 \mathrm{bp}$, which will release two fragments of 611 and 461 bp upon ApaI digestion. As shown in Figure S1A, the diagnostic PCR and ApaI digestion produced the expected results, and all of mutants were real OX gene disrupted mutants.

A
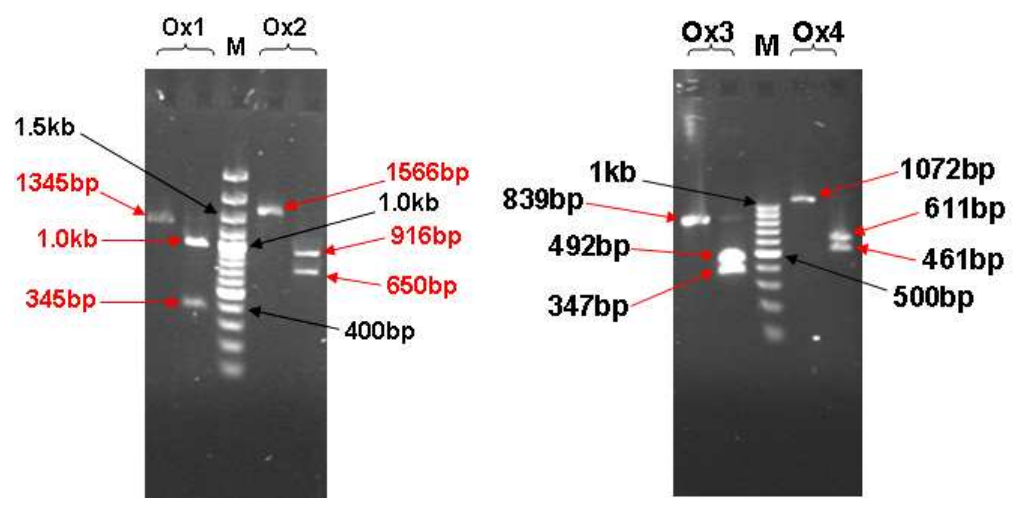

B

$\mathbf{m V}$

$25070 \times$
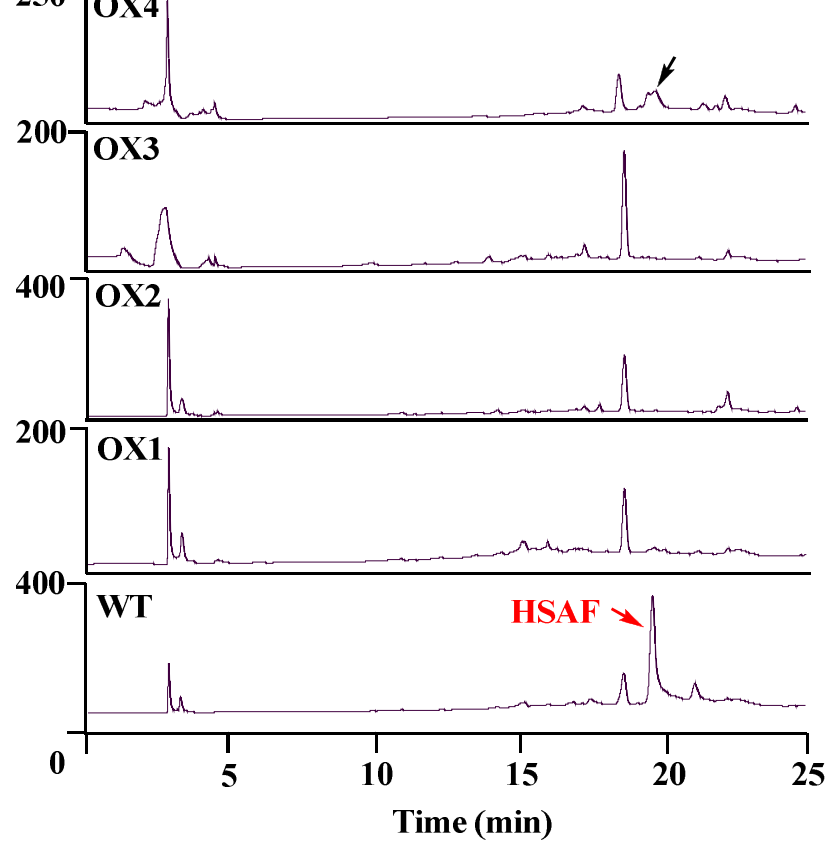
Figure S1. (A) Diagnostic PCR and restriction enzyme digestion of the PCR products to verify the OX mutants. (B) HPLC analysis of the metabolites produced by the OX gene disrupted mutants. The putative maltophilin peak produced by the OX4 mutant and the HSAF peak produced by the wild type strain are indicated with an arrow.

To analyze the metabolites, the mutants were grown in 1/10 TSB medium containing gentamicin $(20 \mu \mathrm{g} / \mathrm{ml})$. The procedure for metabolite extraction and analysis was the same as

described previously. ${ }^{1}$ The results showed that the gene disruption mutants of OX1, OX2, and OX3 did not produce any detectable HSAF, whereas the OX4 mutants produced a small amount of a metabolite with a $[\mathrm{M}+\mathrm{H}]^{+}$of 511 , which is two mass units smaller than HSAF (Figure S1B).

\section{Generation of four OX gene in-frame deletion mutants}

To eliminate the potential polar effect caused by insertion of the conjugal vector, we also generated in-frame deletion mutants for each of the four OX genes. To construct the OX3 inframe deletion vector, primer extension PCR reactions were performed to generate a 593-bp fragment of OX3 gene with an EcoRI site introduced to replace a 27-bp sequence within the gene. This would delete 9 amino acid residues (LVEDDRAVG) within a sequence motif that is highly conserved among the FAD-dependent oxidoreductases. The following primers were used for these experiments.

P1-OX3-For

5'-ATT CTA GAT TCC TCC CCT ACT TCA ACG CCA TCC G-3'

P2-OX3-Rv-Fusion 
5'-GCC CGT CGC TCA GGC GGA GAA TTC GAT CTC CTC GAC TTT CGC-3'

P1'-OX3-For-Fusion

5'-GCG AAA GTC GAG GAG ATC GAA TTC TCC GCC TGA GCG ACG GGC-3'

P2'-OX3-Rv

\section{5'-ATC TCG AGA CTG CAC GTT GAT GCT CGG GTG GCG-3'}

Genomic DNA of L. enzymogenes $\mathrm{C} 3$ was used as template and the enzyme was Phusion HF polymerase (New England BioLabs). The PCR program was as follows: denaturation at $98{ }^{\circ} \mathrm{C}$ for $5 \mathrm{~min}$, followed by 35 cycles of $98{ }^{\circ} \mathrm{C}$ for $30 \mathrm{sec}, 65^{\circ} \mathrm{C}$ for $30 \mathrm{sec}$ and $72{ }^{\circ} \mathrm{C}$ for $40 \mathrm{sec}$. To amplify the complete OX3 in-frame deletion cassette, the upstream homologous region (left arm, LA) was amplified with P1-OX3-For/P2-OX3-Rv-Fusion and the downstream homologous region (right arm, RA) was amplified with P1'-OX3-For-Fusion/P2-OX3-Rv. Purified PCR products from the first step served both as template and the primers for extension PCR that runs 11 cycles of amplification under the same condition in a $20 \mu \mathrm{l}$ PCR system. Primers P1-OX3For/P2'-OX3-Rv were then added to further amplify the fusion PCR products for 20 cycles. The fusion product was subjected to $1 \%$ agarose gel analysis. The product with the desired size was purified from the gel and served as the template to amplify the fusion PCR product for 35 cycles in a $40 \mu \mathrm{l} \mathrm{PCR} \mathrm{system.} \mathrm{The} \mathrm{fragment} \mathrm{was} \mathrm{then} \mathrm{cloned} \mathrm{into} \mathrm{the} \mathrm{conjugal} \mathrm{vector} \mathrm{pJQ200SK} \mathrm{as} \mathrm{an}$ XhoI/XbaI fragment to produce pJQ200SK-OX3 (Figure S2A and B).

To construct the OX4 gene in-frame deletion vector, a 525-bp fragment was amplified from OX4 gene, with an EcoRI site introduced to replace a 33-bp sequence within the gene. This would delete 11 amino acid residues (PFRPGDLVQGF) within a sequence motif that is highly 
conserved among the $\mathrm{Zn}$-dependent alcohol dehydrogenases. The following primers pairs were used for these experiments.

P1-OX4-For

5'-ATA CTA GTG ACC GCA AGC ACA TGA AGA CCG AAC G-3'

P2-OX4-Rv-Fusion

5'-AGG TGC GTG CGC CAG CCG CCG AAT TCC GCG TTC GGG CCG GCA TCG A-3'

P1'-OX4-For-Fusion

5'-TCG ATG CCG GCC CGA ACG CGG AAT TCG GCG GCT GGC GCA CGC ACC T$3^{\prime}$

P2'-OX4-Rv

5'-ATC TCG AGA ACC AGG GTG CCG ATC ATG CCC GAG G-3'

To amplify the complete OX4 in-frame deletion cassette, the left arm was amplified with P1OX4-For/P2-OX4-Rv-Fusion and the right arm was amplified with P1'-OX4-For-Fusion/ P2OX4-Rv. The same PCR program as OX3 was used. The fragment was then cloned to the conjugal vector pJQ200SK as an XhoI/SpeI fragment to produce pJQ200SK-OX4 (Figure S3A and B).

To conjugally transfer pJQ200SK-OX4 and pJQ200SK-OX3 into L. enzymogenes strain C3, the procedure was identical to the previously described. ${ }^{1}$ To screen the single crossover mutants, the genomic DNA was prepared from 1/10 TSB cultures of the individual colonies. For the OX3- 
deletion mutants, primers P1 (5'-AAG TAG GTG GCG TAG ACG-3') and P2 (5'-CCC TCA TCA GTG CCA ACA TAG-3') were used to screen the left arm single crossover mutants (Figure S2C). A 1002-bp fragment was expected from the positive colonies. The OX4-deletion mutants were identified similarly using primers N1 (5'-TTC TGC TCG GTG AAC CAC TCC-3') and N2 (5'-CCC TCA TCA GTG CCA ACA TAG-3') (Figure S3C). A 1281-bp fragment was expected from the positive colonies. For both PCR reactions, the genomic DNA of wild type $L$. enzymogenes served as the template for a negative control. No product with expected size was observed in the negative control.

The single colonies identified from single crossover were subjected to liquid cultures containing 5\% (W/V) sucrose to select for the loss of the vector through a second homologous recombination. The single crossover mutants were grown in 1/10 tryptic soy broth (TSB) medium for 14 hours. Then the individual cultures were re-inoculated into 1/10 TSB (with 1:100 ratio) containing $5 \%$ sucrose and $25 \mu \mathrm{g} / \mathrm{ml}$ kanamycin medium. Aliquots $(50 \mu \mathrm{l})$ were taken out every 3 hours from this liquid culture and spread onto $1 / 10$ TSA plates (5\% sucrose, $25 \mu \mathrm{g} / \mathrm{ml}$ kanamycin). Single colonies were picked up from the plates and continued to grow in 1/10 TSB (5\% sucrose, $25 \mu \mathrm{g} / \mathrm{ml}$ kanamycin) liquid medium for another 2-5 days.

To confirm the double crossover mutants, the genomic DNA was prepared from 1/10 TSB cultures of the individual single colonies. OX3 double crossover mutants were screened using primers P1 (5'-AAG TAG GTG GCG TAG ACG-3') and P3 (5'-TAT CCC TTC CTC AAG CCG-3'), which amplify a 702-bp fragment from the positive mutants. An EcoRI digestion of this fragment yielded two products of 349-bp and 352-bp, as expected (Figure S2D and S4A, lane 1 and 2). The EcoRI digestion also gave a band around $700 \mathrm{bp}$, in addition to the expected 
bands. A careful examination of the gel indicated that the PCR using primers P1/P3 gave two very close bands around $700 \mathrm{bp}$, one being the expected 702-bp product (which was cut into 349bp and 352-bp by EcoRI) and the other likely being an unspecific product, probably amplified from a homologous sequence such as OX1 and OX2 (with 70\%/80\% of identity/similarity). To confirm this, we further digested the PCR product using another enzyme, SmaI, which is a naturally present site in OX3 gene. Upon SmaI digestion, the 702-bp PCR product was cut into $508 \mathrm{bp}$ and $195 \mathrm{bp}$, as expected, whereas the around 700-bp band remained uncut (Figure S4A, lane 5 and 6). Together, the results confirmed the OX3 mutant.

OX4 double crossover mutants were screened using primers N1 (5'-TTC TGC TCG GTG AAC CAC TCC-3') and N3 (5'-TTC CGC AAC TCG CCA CGA CC-3'), which amplify a 902bp fragment from the positive mutants. An EcoRI digestion of this fragment yielded two products of 625-bp and 277-bp, as expected (Figure S3D and S4A, lane-3 and 4).

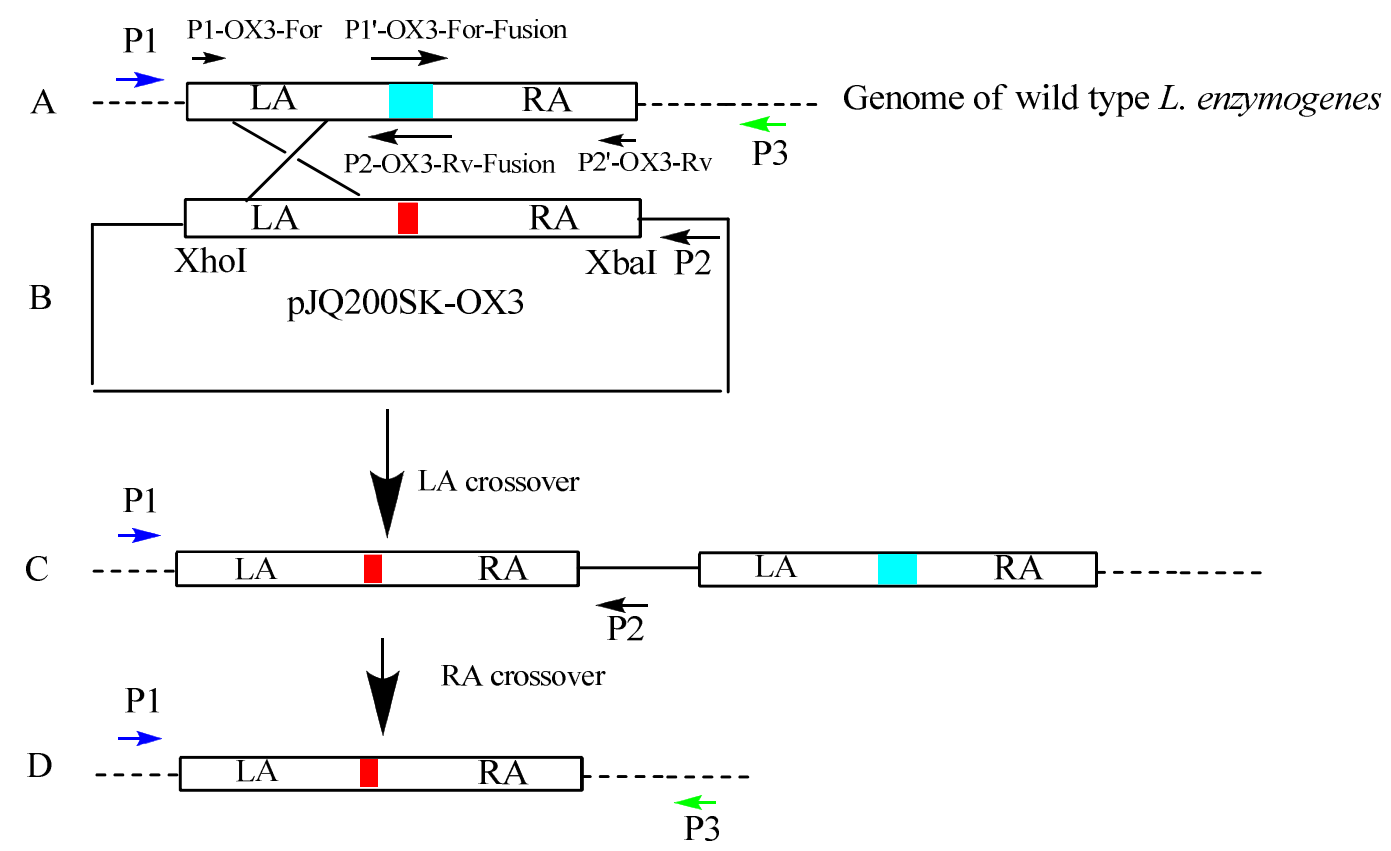


Figure S2. OX3 gene in-frame deletion scheme. The deletion cassette was cloned into conjugal vector pJQ200SK at the XhoI/XbaI sites. Red bar represents the EcoRI site introduced into the host genome to replace a 27-bp sequence of the original gene. Primers P1/P2 were used for screening single crossover mutants, and primers $\mathrm{P} 1 / \mathrm{P} 3$ were used for double crossover mutant screening.

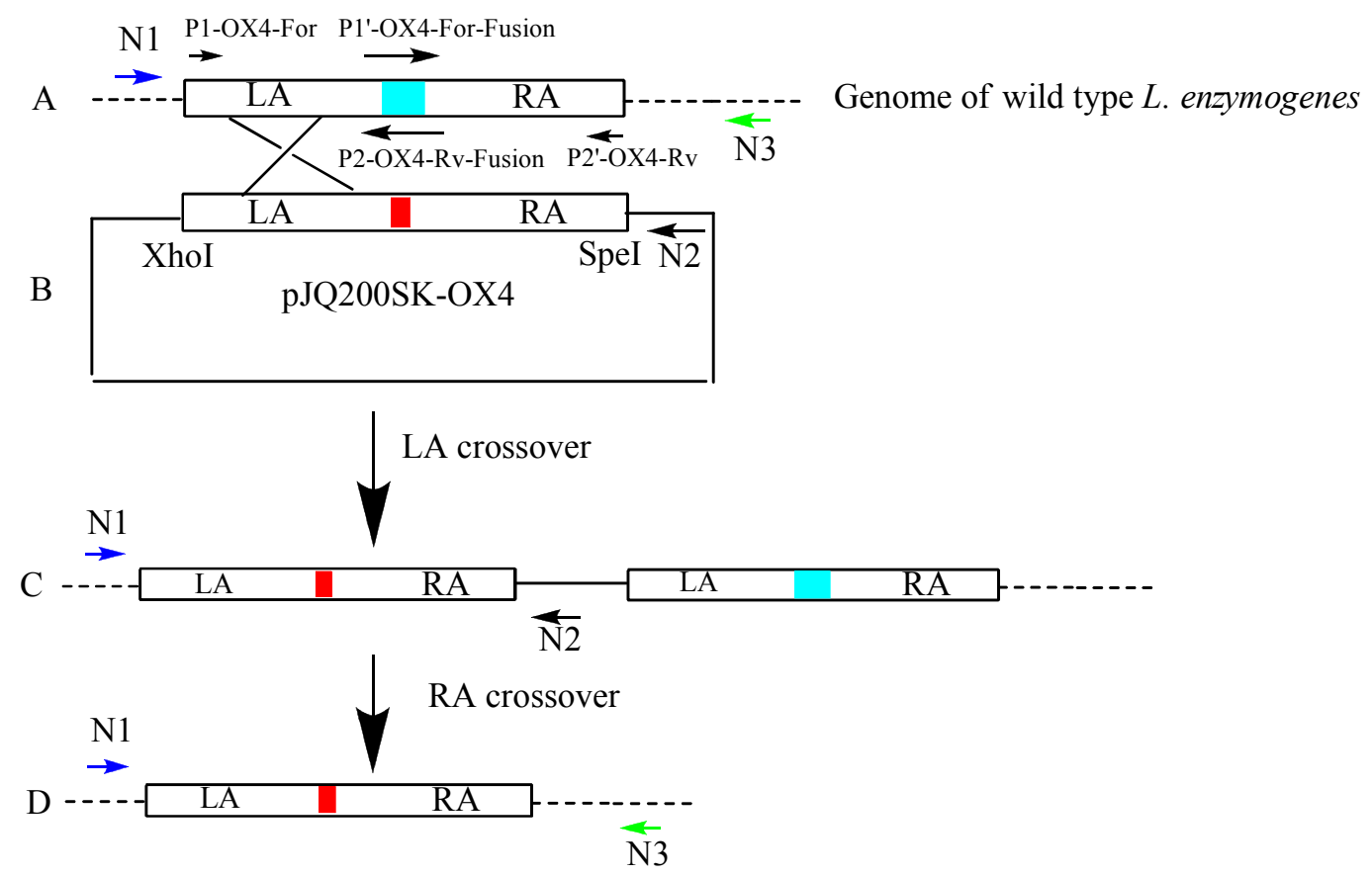

Figure S3. OX4 gene in-frame deletion scheme. The deletion cassette was cloned into conjugal vector pJQ200SK at the XhoI/SpeI sites. Red bar represents the EcoRI site introduced into the host genome to replace a 33-bp sequence of the original gene. Primers N1/N2 were used for screening single crossover mutants, and primers N1/N3 were used for double crossover mutant screening. 
A

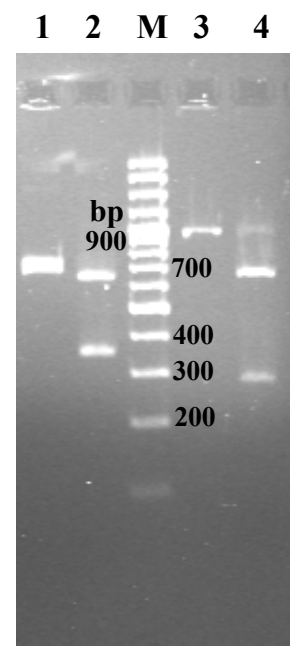

B

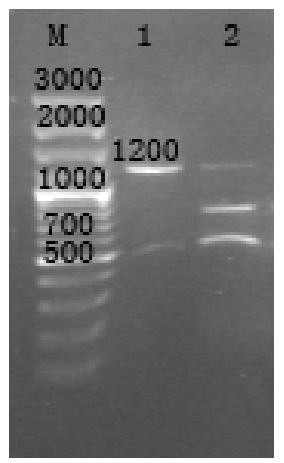

C

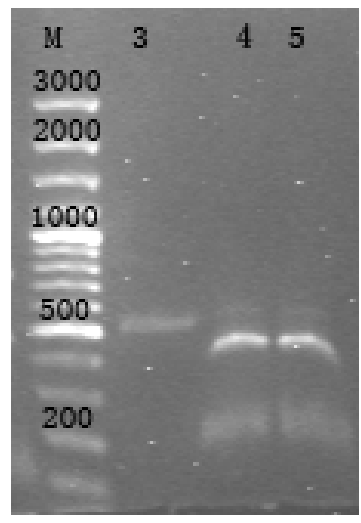

Figure S4. (A) Screening of the OX3 and OX4 in-frame deletion mutants by PCR. Lane 1, undigested PCR product from OX3-double crossover mutant (expecting 702 bp); lane 2, EcoRI digestion of OX3 mutant PCR product (expecting 349 bp and 352 bp); lane 3, undigested PCR product from OX4-double crossover mutant (expecting 902 bp); lane 4, EcoRI digestion of OX4 mutant PCR product (expecting 625 bp and 277 bp); lane M, 100 bp DNA ladder; lane 5, SmaI digestion of OX3 mutant PCR product (expected 508 bp and 195 bp); lane 6, undigested PCR product from OX3 mutant (expected $702 \mathrm{bp})$.

(B) Screening of the OX1 in-frame deletion mutants by PCR. Lane 1, EcoRI digestion of wild type OX1 PCR product (expecting 1198 and 446 bp); lane 2, EcoRI digestion of OX1 mutant PCR product (expecting 736 bp, 462 bp and 446 bp); lane M, 100 bp DNA ladder.

(C) Screening of the OX2 in-frame deletion mutants by PCR. lane 3, EcoRI digestion of wild type OX2 PCR product (expecting 536 bp); lane 4, EcoRI digestion of the OX2 overlapping PCR product (the initial PCR product used to construct the gene deletion vector, as a positive control 
here, expecting $161 \mathrm{bp}$ and $375 \mathrm{bp}$ ); lane 5, EcoRI digestion of OX2 mutant PCR product (expecting $161 \mathrm{bp}$ and $375 \mathrm{bp}$ ); lane M, 100 bp DNA ladder.

To construct the OX1 in-frame deletion vector, a 543-bp fragment of OX1 gene with an EcoRI site introduced to replace a 27-bp sequence within the gene. This would replace 9 amino acid residues (LVEDGRAVG) within a sequence motif that is highly conserved among the FADdependent oxidoreductases. The procedure for generating OX1 in-frame deletion was identical to that for OX3. The following primers were used for these experiments.

OX1-Up-Forw-XhoI:

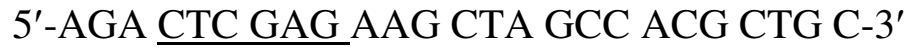

OX1-Up-Revs-EcoRI:

5'-CGT CTC GAA GAC GAA TTC CAG CTC TAC CAC CCG GTC GAC GCG GGT-3'

OX1-Down-forw-EcoRI:

5'-GTA GAG CTG GAA TTC GTC TTC GAG ACG GTA CGG CTC AAG AAC GGC-3'

OX1-Down-Rev-BamHI:

5'- ACT GGA TCC CGA CTC GCC GGC CGG CA-3'

The following primers were used to screen for OX1 single crossover mutants. A 1083-bp fragment was produced from the positive colonies.

P1-OX1 5'-TAA GGA TCC GCC GGC ATG GCC ACC G -3' 


\section{P2-OX1 5'-ACC ATG ATT ACG CCA AGC-3'}

The OX1 double crossover mutants were screened using primers P1-OX1 and P3-OX1, which amplified a 1644-bp fragment from the positive mutants. An EcoRI digestion of this fragment yielded three products of 736-bp, 462-bp and 446-bp, as expected (Figure S4B).

\section{P3-OX1 5'-TCA CTC GAG TCA GGC GGC CGG AAG C-3'}

To construct the OX2 gene in-frame deletion vector, a 536-bp fragment was amplified from OX2 gene, with an EcoRI site introduced to replace an 18-bp sequence within the gene. This would replace 6 amino acid residues (GGGVGG) within a sequence motif that is highly conserved among the FAD-dependent oxidoreductases. The procedure for generating OX2 inframe deletion was identical to that for OX3. The following primers pairs were used for these experiments.

OX2-UP-Forw-XhoI:

5'-CCA CTC GAG CCC GAC CAT GCC GCA C-3'

OX2-Up-Revs-EcoRI:

5'-TGC GCC GAA TTC GCC AGC GAT GAC GAT CAC CCG CGG CGT-3'

OX2-Down-Forw-EcoRI:

5'-GCT GGC GAA TTC GGC GCA CTG TCC ACC GGC GTC TAC GGC-3'

OX2-Down-Revs-BamHI: 


\section{5'-CTT GGA TCC GCG GCG CAG GTC GGC-3'}

The following primers were used to screen for OX2 single crossover mutants. A 657-bp fragment was produced from the positive colonies.

\section{N1-OX2 5'-ACC ACG AGG ACC CGA CCA TGC-3'}

\section{N2-OX2 5'-ACC ATG ATT ACG CCA AGC-3'}

The OX2 double crossover mutants were screened using primers N3-OX2 and N4-OX2, which amplified a 536-bp fragment from the positive mutants. An EcoRI digestion of this fragment yielded two products of 161-bp and 375-bp, as expected (Figure S4C).

\section{N3-OX2 5'- CCACTCGAGCCCGACCATGCCGCAC -3'}

\section{N4-OX2 5' - CTTGGATCCGCGGCGCAGGTCGGC -3'}

To analyze the metabolites, the mutants were grown in 1/10 TSB medium containing gentamicin $(20 \mu \mathrm{g} / \mathrm{ml})$. The procedure for metabolite extraction and analysis was the same as

described previously (Figure S5). ${ }^{1}$ Metabolites were collected from HPLC and analyzed by highresolution electronspray ionization mass spectrometry to detect if any HSAF or analog was produced in the mutants. The results showed that the in-frame gene deletion mutants of OX1, OX2, and OX3 did not produce HSAF, whereas the OX4 mutant gave a broad peak on HPLC at the retention time of $\sim 22$ minute (Figure S5A). MS analysis of the main metabolite showed a $[\mathrm{M}+\mathrm{H}]^{+}$of $511.2789(-3.7 \mathrm{ppm})$, which is two mass units smaller than HSAF and coincident 
with the mass of maltophilin (calculated $\mathrm{m} / \mathrm{z} 511.2808$ ), a putative precursor of HSAF (Figure S5B).

A.

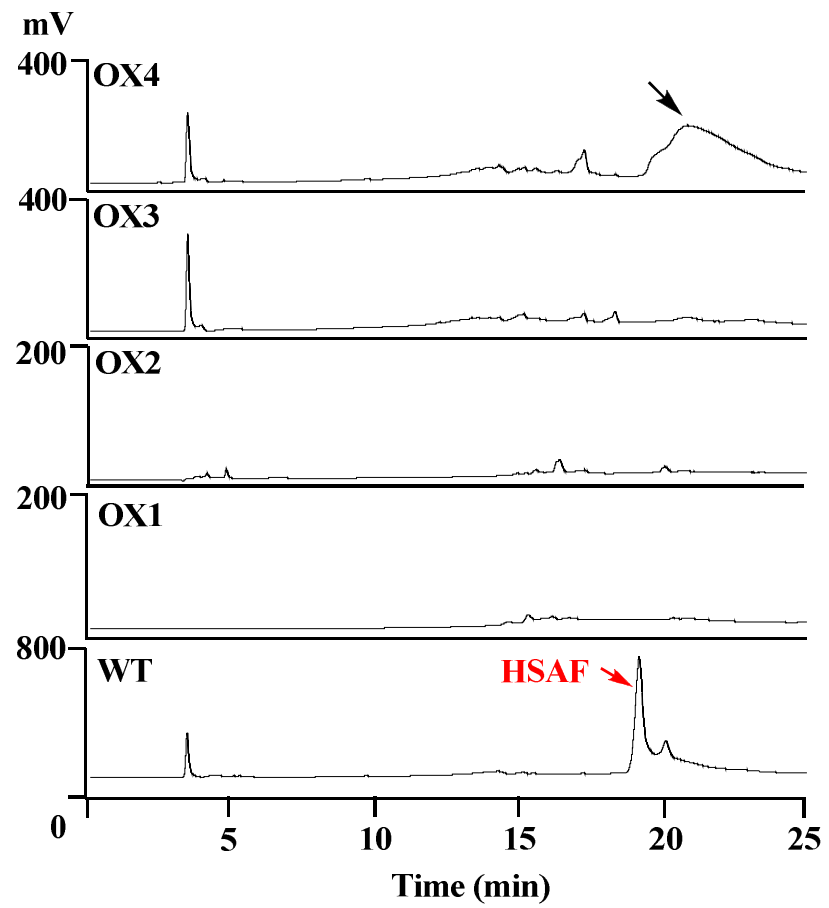

B.

LEC3 (HPLC16-24) OX4-5

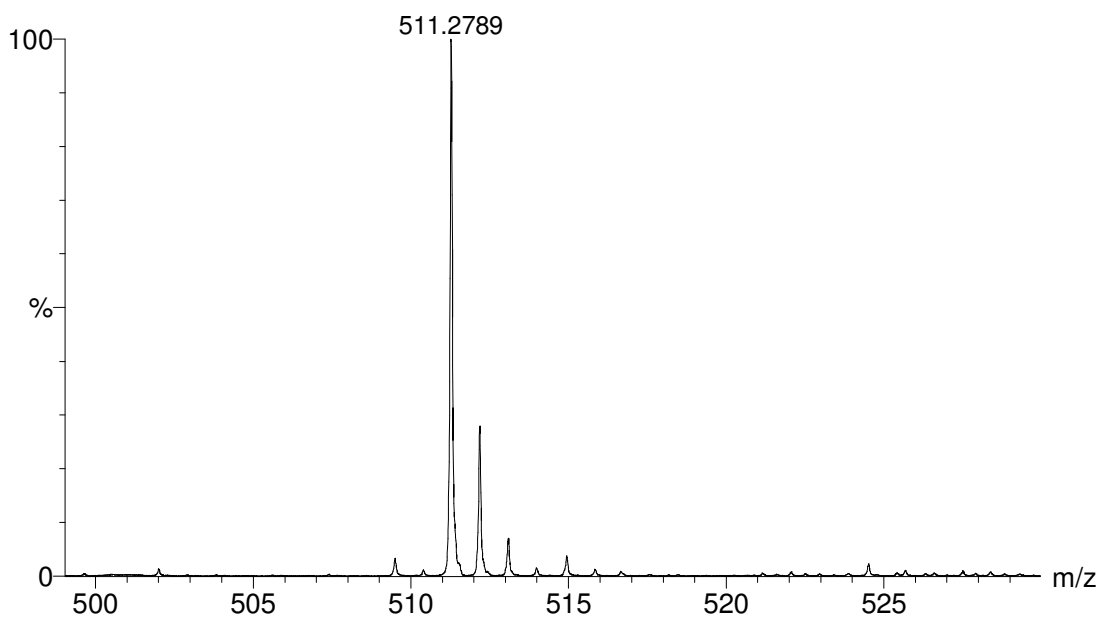


Figure S5. (A) HPLC analysis of the metabolites produced by the four OX gene in-frame deletion mutants. The putative maltophilin peak produced by the OX4 mutant and the HSAF peak produced by the wild type strain are indicated with an arrow. (B) MS analysis of the peak at 22 minute in the OX4 mutant in (A).

\section{Mapping of the HSAF locus}

We used the 20280-bp HSAF gene cluster (EF028635.2) identified from Lysobacter enzymogenes $\mathrm{C} 3$ to search the genome sequences of L. enzymogenes $\mathrm{OH} 11$. All the genes previously identified from strain $\mathrm{C} 3$ were also present in strain $\mathrm{OH} 11$. In addition, we analyzed the regions upstream $(\sim 44 \mathrm{~kb})$ and downstream $(\sim 66 \mathrm{~kb})$ to the HSAF locus. Immediately upstream to the OX4 gene was a MFS transporter (ORF1) and a $4.3 \mathrm{~kb}$ region that did not contain any obvious ORF (Figure S6). Three ORFs (ORF-A, B, and C) were identified further upstream to the $4.3 \mathrm{~kb}$ gap region. In the downstream region, eleven ORFs (ORF-D through $\mathrm{N}$ ) were identified, and the majority of these ORFs appear to encode genes related to DNA repairing and cellular communications and transportations. These ORFs are listed in Figure S6.

\begin{tabular}{|c|c|c|c|c|c|}
\hline ORF & \# nucleotides & $\# \mathbf{a a}$ & Blastp Homolog & $\%$ identity/Similarity & E-value \\
\hline ORF-A & $3356-4444$ & 362 & SGNH-hydrolase (lipase/esterase) & $57 / 73$ & $9 \mathrm{e}-116$ \\
\hline ORF-B & $4568-7621$ & 1017 & Apolipoprotein $N$-acyltransferase & $47 / 60$ & $4 \mathrm{e}-120$ \\
\hline ORF-C & $8024-9439$ & 471 & Amino acid permease & $58 / 72$ & $9 \mathrm{e}-150$ \\
\hline ORF-D & $38747-39271$ & 174 & Competence-damaged protein & $73 / 83$ & $9 \mathrm{e}-63$ \\
\hline ORF-E & $39450-40391$ & 313 & MarR family transcriptional regulator & $53 / 68$ & $6 e-83$ \\
\hline ORF-F & $40512-41174$ & 220 & LexA repressor & $78 / 85$ & $2 \mathrm{e}-90$ \\
\hline ORF-G & $41444-42496$ & 350 & Recombinase A & $85 / 90$ & $2 \mathrm{e}-168$ \\
\hline ORF-H & 42621-43496 & 291 & Regulatory protein RecX & $72 / 84$ & $9 \mathrm{e}-55$ \\
\hline ORF-I & $43662-46295$ & 877 & Alanyl-tRNA synthetase & $78 / 86$ & 0.0 \\
\hline ORF-J & $46440-46643$ & 67 & Carbon-storage regulator, global regulator & $89 / 89$ & $6 \mathrm{c}-22$ \\
\hline ORF-K & $47516-48247$ & 243 & Two-component system regulatory protein & $74 / 82$ & $6 e-94$ \\
\hline ORF-L & $48244-50964$ & 906 & Two-component system sensor protein & $70 / 80$ & 0.0 \\
\hline ORF-M & $51566-52165$ & 199 & $\mathrm{~K}^{+}$-transporting ATPase subunit $\mathrm{C}$ & $65 / 70$ & $8 e-57$ \\
\hline ORF-N & $52244-54306$ & 687 & $\mathrm{~K}^{+}$-transporting ATPase subunit B & $71 / 83$ & 0.0 \\
\hline
\end{tabular}

Figure S6. Annotation of the flanking regions of the HSAF biosynthetic genes. 


\section{Adenylation domain expression and ATP-PPi exchange assays}

To construct the expression vector, a $1731 \mathrm{bp}$ fragment was amplified by PCR using Pfu DNA polymerase and the cosmid COS8-1 as template, which contains part of the HSAF gene cluster. The forward primer was 5'-TTA GGA TCC ACC CGG CTG CCG GCG CAG-3', and the reverse primer was 5'-CCG CTC GAG TCA CAG CAA CTG CTT CCA GTG-3'. The PCR fragment was digested with $\mathrm{BamHI}$ and $\mathrm{XhoI}$ and cloned into pANT841 at the same sites. The construct was sequenced, and the result showed that the A-domain sequence was correct. The Adomain was released from pANT841 as a BamHI/XhoI fragment and cloned into expression vector pET28a. To express the A-domain, the pET28a construct was introduced into $E$. coli BL21 (DE3). Single colonies were inoculated in $3 \mathrm{ml}$ of liquid LB medium containing kanamycin $(50 \mu \mathrm{g} / \mathrm{ml})$ and incubated in a shaker $(250 \mathrm{rpm})$ at $37^{\circ} \mathrm{C}$ overnight. The overnight culture was added to $50 \mathrm{ml}$ fresh $\mathrm{LB}$ medium and incubated in a shaker $(250 \mathrm{rpm})$ at $37^{\circ} \mathrm{C}$ until the cell density $\left(\mathrm{OD}_{600}\right)$ reached 0.6 . To induce the expression of the A domain, IPTG $(0.1 \mathrm{mM})$ was added to the culture, and the cells were allowed to grow at the same conditions for another 3 h. To prepare the soluble fraction, the cells were harvested and resuspended in $2 \mathrm{ml}$ of PBS

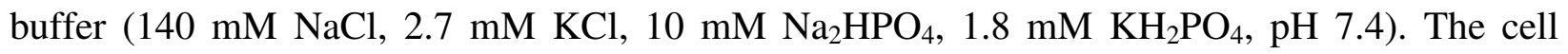
suspension was added with lysozyme $(1 \mathrm{mg} / \mathrm{ml})$ and sonicated five times on ice. The soluble fraction of protein extracts was loaded onto a Ni-NTA column which was previously calibrated with PBS buffer containing $10 \mathrm{mM}$ imidazole. The column was washed three times with the buffer containing $20 \mathrm{mM}$ imidazole, and the His ${ }_{6}$-tagged protein was eluted twice with $200 \mu \mathrm{l}$ of PBS buffer containing $250 \mathrm{mM}$ imidazole (Figure S7). The fractions containing pure A-domain were collected and dialyzed against PBS buffer containing $15 \%$ glycerol. 
A

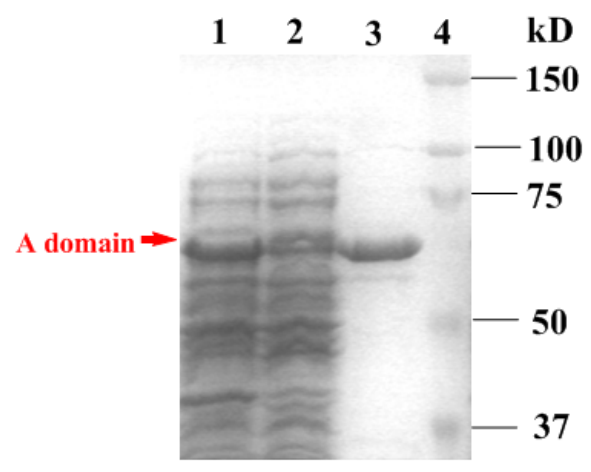

B

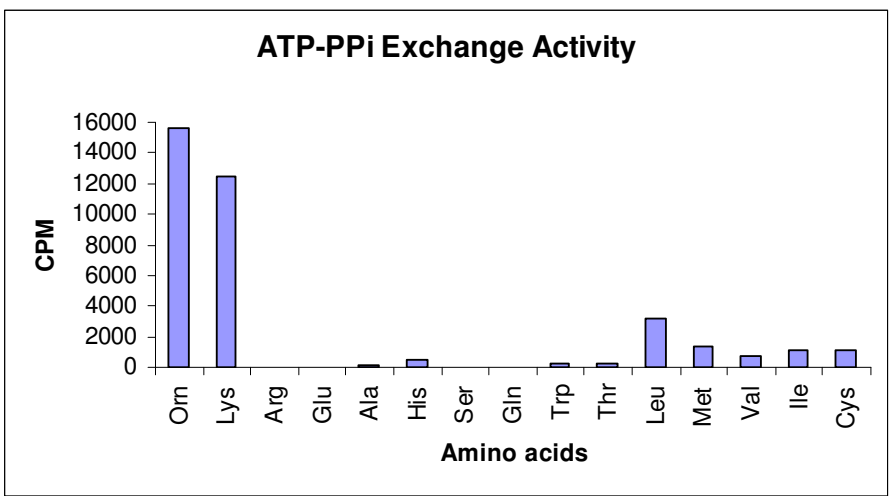

Figure S7. (A) Expression and purification of the adenylation domain of the hybrid

PKS/NRPS. Lane-1, total proteins upon IPTG induction; lane-2, the soluble fraction; lane-3, the purified A-domain. (B) ATP-PPi exchange assay for the adenylation domain.

To test the activity of the A-domain, the ATP-PPi exchange assay was used (Figure S7). ${ }^{2}$ Sixteen amino acids were tested as substrates. The reactions contained one amino acid (1 mM), A-domain protein $(180 \mathrm{nM}),{ }^{32} \mathrm{P}-\mathrm{PPi}(0.6 \mu \mathrm{Ci}, 80.47 \mathrm{Ci} / \mathrm{mmol}$, PerkinElmer Life and Analytical Sciences, Downers Grove, IL) in sodium phosphate buffer (50 mM, pH 7.8) containing EDTA (0.1 mM), $\mathrm{MgCl}_{2}(1 \mathrm{mM})$ and ATP $(1 \mathrm{mM})$, in a final volume of $100 \mu \mathrm{l}$. ATP and the ${ }^{32} \mathrm{P}-\mathrm{PPi}$ were added at the end, and the reactions were incubated 15 min at $30^{\circ} \mathrm{C}$. 


\section{Whole NRPS module expression}

To express the four-domain NRPS module of HSAF hybrid PKS/NRPS, a 3966 bp fragment was amplified by PCR using Pfu DNA polymerase and the cosmid COS8-1 as template. The forward primer was C-NcoI-Fw, 5'-TAA TCC ATG GAG CAG TTG CAT GCC GGC CTG GTC GAG-3', and the reverse primer was TE-BamHI-Rv, 5'-TTA GGA TCC GGC GAC ATG GCC CGT CTC CCC-3'. The resulting PCR product was initially ligated into pANT841. After the insert was verified by restriction enzyme digestions and DNA sequencing, it was transferred to pQE60. This expression construct was then introduced into E. coli SG13009 (pREP4). Single colonies were inoculated in LB supplemented with $50 \mu \mathrm{g} / \mathrm{ml}$ ampicillin and $25 \mu \mathrm{g} / \mathrm{ml}$ kanamycin and were grown to $\mathrm{OD}_{600}=0.7$ at $37^{\circ} \mathrm{C}$. The cultures were cooled for 20 min at $4{ }^{\circ} \mathrm{C}$, and IPTG $(0.5 \mathrm{mM})$ was added to the cultures, which were allowed to grow for an additional 14 $\mathrm{h}$ at $25^{\circ} \mathrm{C}$. The cells were harvested and resuspended in $20 \mathrm{mM}$ PBS, pH 7.8, containing $5 \mathrm{mM}$ imidazole, $500 \mathrm{mM} \mathrm{NaCl}, 1 \mathrm{mg} / \mathrm{mL}$ lysozyme, $1 \mathrm{mM}$ PMSF, and 0.5\% Triton X-100. The mixtures were incubated on ice for $30 \mathrm{~min}$, followed by sonication and centrifugation. The soluble fraction was loaded onto a Ni-NTA column (Qiagen), and the C-His ${ }_{6}$-tagged NRPS protein $(148.6 \mathrm{kDa})$ was purified by using an imidazole step-gradient as described by the manufacturer's protocol. The purity of the protein was analyzed by SDS-PAGE, and the fractions containing purified protein were pooled, concentrated, and dialyzed against $20 \mathrm{mM}$ PBS, $50 \mathrm{mM} \mathrm{NaCl}$, pH 7.8, 15\% glycerol. Finally the protein solution was frozen in liquid nitrogen and stored at $-80{ }^{\circ} \mathrm{C}$ until use.

\section{In vitro assay for the activity of the NRPS module}


To test the activity of the NRPS module, the first step was to prepare an acyl-ACP substrate and holo-NRPS. The acyl-ACP substrate was obtained by incubating stearoyl-CoA $(0.67 \mathrm{mM})$ and Fum1p-ACP $(49 \mu \mathrm{M}){ }^{3}$ with $\operatorname{Svp}(5.6 \mu \mathrm{M}){ }^{4}$ in a $50 \mu 1$ reaction containing Tris- $\mathrm{HCl}(100$ $\mathrm{mM}, \mathrm{pH}$ 8.0). The reason to use Fum1p-ACP was that the ACP of hybrid PKS-NRPS for HSAF biosynthesis could not be expressed heterologously. We tried both the T5 promoter-based expression system (such as pQE60) and the T7 promoter-based expression system (such as pET28a), and expressed it under different conditions (temperatures and IPTG concentrations). However, this ACP appeared to be refractory for heterologous expression.

The holo-NRPS was obtained by incubating C-A-PCP-TE $(3 \mu \mathrm{M})$ and CoA $(0.83 \mathrm{mM})$ wih $\operatorname{Svp}(5.6 \mu \mathrm{M})$ in a $60 \mu \mathrm{l}$ reaction containing Tris- $\mathrm{HCl}(100 \mathrm{mM}, \mathrm{pH} 8.0), \mathrm{MgCl}_{2}(10 \mathrm{mM})$, and TCEP $(0.5 \mathrm{mM})$. Both reactions were incubated at $37^{\circ} \mathrm{C}$ for $2 \mathrm{~h}$. Finally, these two reaction mixtures were combined into a tube containing a $40 \mu 1$ solution containing L-Orn $(1.5 \mathrm{mM})$, ATP (3 mM), Tris-HCl (100 mM, pH 8.0), $\mathrm{MgCl}_{2}$ (10 mM), NaCl (50 mM), EDTA (0.1 mM), and TCEP $(0.5 \mathrm{mM})$. A reaction without C-A-PCP-TE protein served as the control. After continual incubation for $50 \mathrm{hr}$ at $37^{\circ} \mathrm{C}$, the reactions were stopped by adding $150 \mu \mathrm{lof} 0.2 \mathrm{mM}$

TCA in methanol and were frozen at $-20^{\circ} \mathrm{C}$ for $30 \mathrm{~min}$. The mixtures were centrifuged at 13,200 
rpm for 20 min in a desktop Eppendorf centrifuge, and the supernatants were transferred to new tubes. The solutions were dried in a Speed-Vac, and the residues in the tubes were re-dissolved in $150 \mu \mathrm{l}$ methanol. The methanol solutions were centrifuged, transferred to new tubes, and dried again. Finally, the products were re-dissolved in $20 \mu 1$ methanol (containing $5 \mathrm{mM}$ ammonium acetate) and analyzed by LC Q-TOF (Waters; Micromass UK, Beverly, MA, USA) equipped with Shimadzu system controller SCL-10A and two pumps LC-10AT and LC-10AD. The LCMS column was Alltima C18LL $(5 \mathrm{u}, 1.0 \mathrm{~mm} \times 250 \mathrm{~mm})$. Solvent A was $\mathrm{H}_{2} \mathrm{O}$ containing $5 \mathrm{mM}$ ammonium acetate; Solvent $\mathrm{B}$ was $\mathrm{MeOH}$ containing $5 \mathrm{mM}$ ammonium acetate. The flow rate was $50 \mu \mathrm{l} / \mathrm{min}$, with a binary gradient system (0-5 min, 30\% B; 5-20 min, 30\% B to $100 \% \mathrm{~B}$ gradient; $20-30$ min, $100 \%$ B; 30-40 min, 100\% B to 30\% B gradient; 40-45 min, 30\% B).

\section{Chemical synthesis of tetramic acid 8}

Overview of tetramic acid synthesis: An authentic sample of the proposed tetramic acid structure was prepared as illustrated in Scheme SI-1. The boroxazolidinone adduct of $L$-ornithine $(9)^{1}$ was selectively acylated at the terminal amino group with octadecanoyl chloride to furnish a monoamide. Deprotection of the boroxazolidinone with ethylenediamine, ${ }^{5}$ followed by reaction with thionyl chloride in methanol furnished methyl ester 10. Conversion of the amino acid ester to the tetramic acid was accomplished through a Dieckmann reaction ${ }^{6,7}$ based upon a modification of a published approach. ${ }^{8}$ Condensation of the amino ester with 2benzyloxycarbonyl-octacadecanoic acid 11, prepared in two steps from dibenzyl malonate, furnished the bisamide 12 as an inseparable $\sim 1: 1$ mixture of diastereomers. ${ }^{8}$ Reaction with excess sodium hydride resulted in tandem Claisen condensation ${ }^{5}$ and deacylation ${ }^{9}$ to furnish tetramic acid $\mathbf{8}$ as a 1:1 mixture of epimers at $\mathrm{C}_{3}$ of the 3,5-dioxopyrrolidine. 


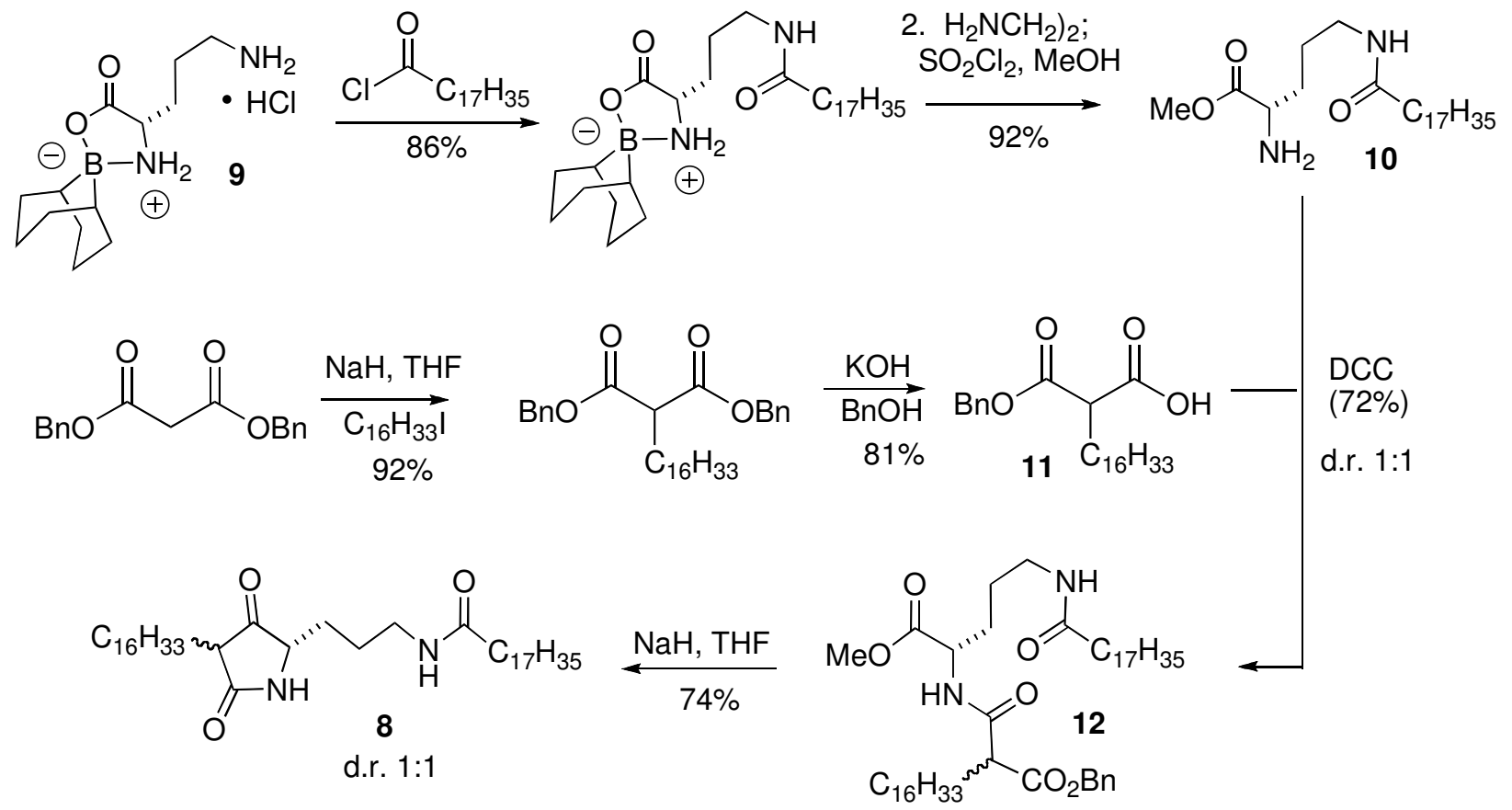

Scheme SI-1. Preparation of the tetramic acid 8

General Synthesis and Characterization Procedures: All reagents and solvents were used as supplied commercially, except $\mathrm{CH}_{2} \mathrm{Cl}_{2}$ and $\mathrm{THF}$, which were distilled from $\mathrm{CaH}_{2}$, and $\mathrm{Na}$ /benzophenone, respectively. Melting points are uncorrected. Unless noted, NMR spectra were acquired at $400 \mathrm{MHz}\left({ }^{1} \mathrm{H}\right)$ or $100 \mathrm{MHz}\left({ }^{13} \mathrm{C}\right)$ in $\mathrm{CDCl}_{3}$. IR spectra were recorded as neat films on a $\mathrm{ZrSe}$ crystal with selected absorbances reported in $\mathrm{cm}^{-1}$. Mass spectroscopy was conducted at the Nebraska Center for Mass Spectrometry.

\section{L-ornithine monohydrochloride, 9-borabicyclononane complex (9)}




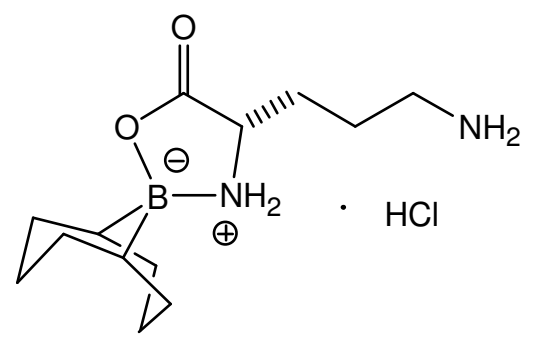

Compound 9 was prepared by the procedure of Fields from L-ornithine monohydrochloride. ${ }^{5}$ The product, which retained solvent, was carried on into the next procedure without purification.

\section{$\mathrm{N}^{5}$-octadecanoyl-L-ornithine, 9-borabicyclononane complex}

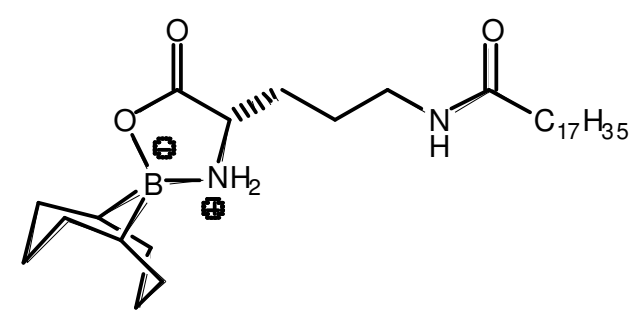

To a solution of compound $9(3.06 \mathrm{~g}, 10 \mathrm{mmol})$ in THF $100 \mathrm{ml}$ was added $\mathrm{Et}_{3} \mathrm{~N}(6.0 \mathrm{ml}, 40$ mmol) and stearoyl chloride ( $4.30 \mathrm{~g}, 12 \mathrm{mmol})$. The reaction mixture was stirred at $\mathrm{rt}$ for $6 \mathrm{~h}$ and then concentrated in vacuo. The residue was dissolved in $200 \mathrm{ml}$ water, and the aqueous layer was extracted with $\mathrm{CH}_{2} \mathrm{Cl}_{2}(100 \mathrm{ml} \times 3)$. The combined organic layers were dried over anhydrous $\mathrm{Na}_{2} \mathrm{SO}_{4}$ and filtered. The residue obtained upon concentration was purified by chromatography $\left(\mathrm{CH}_{2} \mathrm{Cl}_{2} / \mathrm{MeOH}, 95: 5\right)$ to afford the octadecanoic amide as a white solid $(4.40 \mathrm{~g}$, $86 \%), \mathrm{R}_{\mathrm{f}} 0.6\left(\mathrm{CH}_{2} \mathrm{Cl}_{2} / \mathrm{MeOH} 90 / 10\right), \mathrm{Mp} 69-70{ }^{\circ} \mathrm{C} .[\alpha]_{\mathrm{D}}=-13.8\left(\mathrm{CHCl}_{3}, \mathrm{c}=1.0\right) . \quad$ IR 3344, 3128, 3110, 2920, 2850, 1692, 1681, 1544, 1376, 1273, 963, 878, $722 \mathrm{~cm}^{-1} ;{ }^{1} \mathrm{H}$ NMR: $\delta 6.60$ (t, 
$\mathrm{J}=6.4 \mathrm{~Hz}, 1 \mathrm{H}), 5.92(\mathrm{t}, \mathrm{J}=8.8 \mathrm{~Hz}, 1 \mathrm{H}), 5.01(\mathrm{t}, \mathrm{J}=9.6 \mathrm{~Hz}, 1 \mathrm{H}), 3.78(\mathrm{t}, \mathrm{J}=6.3 \mathrm{~Hz}, 1 \mathrm{H}), 3.28(\mathrm{~m}$, 1H), $3.20(\mathrm{~m}, 1 \mathrm{H}), 2.16(\mathrm{t}, \mathrm{J}=7.1 \mathrm{~Hz}, 2 \mathrm{H}), 2.05(\mathrm{~m}, 1 \mathrm{H}), 1.94-1.12(45 \mathrm{H}), 0.88(\mathrm{t}, \mathrm{J}=6.9 \mathrm{~Hz}, 3 \mathrm{H})$, 0.57 (d, J= 10.8 Hz, 2H); ${ }^{13} \mathrm{C}$ NMR: 175.0, 174.3, 55.1, 38.7, 36.7, 31.9, 31.7, 31.4, 31.3, 31.2, $29.73,29.67,29.58,29.44,29.41,29.36,28.1,26.4,25.9,24.5,24.0,22.7,14.1 ; \mathrm{HRMS}(\mathrm{m} / \mathrm{z})$ calcd for $\mathrm{C}_{31} \mathrm{H}_{59} \mathrm{BN}_{2} \mathrm{NaO}_{3}[\mathrm{M}+\mathrm{Na}]^{+}$: 541.4516 ; found: 541.4514 (-0.4 ppm).

\section{L-ornithine, $\mathrm{N}^{5}$-octadecanoylamide, methyl ester (10)}

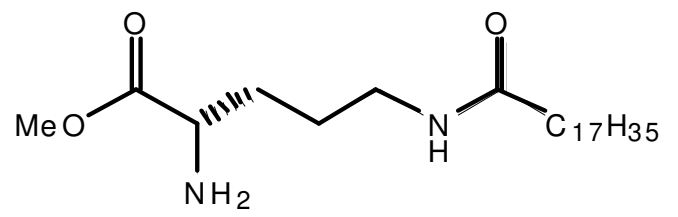

10

Ethylene diamine $(1.7 \mathrm{ml}, 25 \mathrm{mmol})$ was added to a solution of $\mathrm{N}^{5}$-octadecanoyl-L-ornithine, 9borabicyclononane complex $(2.80 \mathrm{~g}, 5.5 \mathrm{mmol})$ in THF $(15 \mathrm{ml}) .^{5}$ The solution was heated to just below boiling for $1 \mathrm{~min}$, and then cooled and filtered. The precipitate was washed with THF $(25 \mathrm{ml} \times 3)$, and dried in vacuo to give a white solid, which was suspended in $\mathrm{MeOH}(100 \mathrm{ml})$. $\mathrm{SOCl}_{2}(1.9 \mathrm{ml}, 25 \mathrm{mmol})$ was added dropwise, and the reaction mixture was refluxed for $2 \mathrm{~h}$. After removal of solvent in vacuo, the residue was dissolved in water $100 \mathrm{ml}$. The solution was adjusted to $\mathrm{pH} 10$ with sat. aq. $\mathrm{K}_{2} \mathrm{CO}_{3}$, and then extracted with $\mathrm{CH}_{2} \mathrm{Cl}_{2}(50 \mathrm{ml} \times 3)$. The combined organic layers were dried over anhydrous $\mathrm{Na}_{2} \mathrm{SO}_{4}$, and the filtrate concentrated in vacuo to afford $\mathbf{1 0}$ as a white solid $(2.26 \mathrm{~g}, 92 \%)$, which was used without further purification. $\mathrm{R}_{\mathrm{f}}$ $0.3\left(\mathrm{CH}_{2} \mathrm{Cl}_{2} / \mathrm{MeOH} / \mathrm{NEt}_{3} 90 / 10 / 1\right), \quad \mathrm{Mp} 59-61^{\circ} \mathrm{C} ;[\alpha]_{\mathrm{D}}=-7.1\left(\mathrm{CHCl}_{3}, \mathrm{c}=1.0\right)$. IR 3318, 2916, 2848, 1741, 1646, 1553, 1232, $718 \mathrm{~cm}^{-1} ;{ }^{1} \mathrm{H}$ NMR: $6.01(\mathrm{t}, \mathrm{J}=5.4 \mathrm{~Hz}, 1 \mathrm{H}), 3.70$ (s, 3H), $3.44(\mathrm{t}$, $\mathrm{J}=6.9 \mathrm{~Hz}, 1 \mathrm{H}), 3.24(\mathrm{~m}, 2 \mathrm{H}), 2.13(\mathrm{t}, \mathrm{J}=7.2 \mathrm{~Hz}, 2 \mathrm{H}), 1.60(\mathrm{~m}, 4 \mathrm{H}), 1.30-1.21(32 \mathrm{H}), 0.86(\mathrm{t}, \mathrm{J}=$ 
6.9 Hz, 3H); Traces of an impurity could be seen in the NMR as signals at $3.65 \mathrm{ppm}$ and 2.28 ppm; ${ }^{13}$ C NMR: 176.2, 173.2, 54.0, 52.1, 39.0, 26.8, 32.1, 31.9, 29.67, 29.63, 29.5, 29.37, 29.33, 25.9, 25.8, 22.7, 14.1; HRMS (m/z) calcd for $\mathrm{C}_{24} \mathrm{H}_{48} \mathrm{~N}_{2} \mathrm{NaO}_{3}[\mathrm{M}+\mathrm{Na}]^{+}$(note: we experienced difficulties in achieving adequate dissolution of this sample in a sodium acetate buffer): 435.3563; found: $435.3562(-0.2 \mathrm{ppm})$.

\section{2-(Benzyloxycarbonyl)octadecanoic acid, benzyl ester}

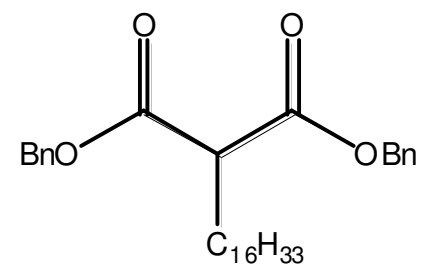

Dibenzylmalonate $(2.84 \mathrm{~g}, 10 \mathrm{mmol})$ was added to a stirred solution of $\mathrm{NaH}(0.24 \mathrm{~g}, 10 \mathrm{mmol})$ in dry $\operatorname{THF}(10 \mathrm{ml})$ and dry $\operatorname{DMF}(10 \mathrm{ml})$ and the mixture was stirred at $\mathrm{rt}$ for $1 \mathrm{~h}$. 1Iodohexadecane $(3.52 \mathrm{~g}, 10 \mathrm{mmol})$ was then added and the reaction mixture was refluxed for $3 \mathrm{~h}$. The cooled reaction mixture was concentrated in vacuo and the residue added to sat. aq. $\mathrm{NH}_{4} \mathrm{Cl}$ $(100 \mathrm{ml})$, and the aqueous layer was extracted by $\mathrm{Et}_{2} \mathrm{O}(100 \mathrm{ml} \times 3)$. The combined organic layers were dried over anhydrous $\mathrm{Na}_{2} \mathrm{SO}_{4}$ and the filtrate was concentrated in vacuo. Flash chromatography (Hexane/EtOAc, 95:5) afforded the diester as a low-melting white solid (4.67 g, 92\%). R 0.3 (Hexane/EtOAc 95/5). Mp 41-42 ${ }^{\circ} \mathrm{C}$; IR 2914, 2848, 1752, 1728, 1463, 1455, 1184,1143, 724, $669 \mathrm{~cm}^{-1} ;{ }^{1} \mathrm{H}$ NMR: 87.34 (m, 10H), 5.19 (s, 4H), $3.48(\mathrm{t}, \mathrm{J}=7.5 \mathrm{~Hz}, 1 \mathrm{H}), 1.97$ (dd, J= 7.1 Hz, 13.8 Hz, 2H), 1.38-1.21 (28H), 0.93 (t, J= 7.0 Hz, 3H); ${ }^{13} \mathrm{C}$ NMR:ס169.3, 135.5, 
$128.6,128.3,128.2,67.0,52.1,32.0,29.73,29.69,29.64,29.5,29.4,29.3,29.2,28.8,27.2,22.7$, 14.2 ; HRMS (m/z) calcd for $\mathrm{C}_{33} \mathrm{H}_{48} \mathrm{NaO}_{4}[\mathrm{M}+\mathrm{Na}]^{+}: 531.3450$; found: 531.3447 (-0.6 ppm).

2-(Benzyloxycarbonyl)octadecanoic acid was prepared by a modification of a procedure reported for malonic acid monobenzyl ester. ${ }^{6}$

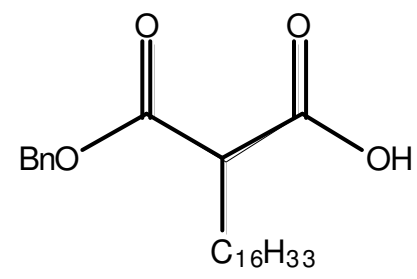

To a suspension of $\mathrm{KOH}(0.28 \mathrm{~g}, 5 \mathrm{mmol})$ in benzyl alcohol $(5.0 \mathrm{ml})$ was added gradually to a solution of the diester $(2.62 \mathrm{~g}, 5 \mathrm{mmol})$ in benzyl alcohol $(25 \mathrm{ml})$. The reaction mixture was stirred at $\mathrm{rt}$ for $24 \mathrm{~h}$, and the solvent was then removed in vacuo. The residue was dissolved in water $(100 \mathrm{ml})$ and the solution acidified to $\mathrm{pH} 2$ with $3 \mathrm{M} \mathrm{HCl}$. The aqueous layer was extracted with $\mathrm{CH}_{2} \mathrm{Cl}_{2}(100 \mathrm{ml} \times 3)$ and then combined organic layers were dried over anhydrous $\mathrm{Na}_{2} \mathrm{SO}_{4}$. The filtrate was concentrated in vacuo to afford a solid which was recrystallized from heptane to afford the monoester as a white solid (1.69 g, 81\%): $\mathrm{R}_{\mathrm{f}} 0.6$ (Hexane/EtOAc/AcOH 20/20/1). Mp 46-48 ${ }^{\circ} \mathrm{C}$; IR 2916, 2848, 1745, 1696, 1470, 1259, 1231, 936, 730, $718 \mathrm{~cm}^{-1}$; ${ }^{1} \mathrm{H}$ NMR: $\delta 10.08$ (br, 1H), $7.40(\mathrm{~m}, 5 \mathrm{H}), 5.23(\mathrm{~s}, 2 \mathrm{H}), 3.47(\mathrm{t}, \mathrm{J}=7.4 \mathrm{~Hz}, 1 \mathrm{H}), 1.97(\mathrm{~m}, 2 \mathrm{H}), 1.40-1.24(28 \mathrm{H}), 0.92$ (t, J= 6.7 Hz, 3H); ${ }^{13} \mathrm{C}$ NMR: 175.2, 169.3, 135,3, 128.6, 128.4, 128.2, 67.3, 51.7, 32.0, 29.73, 29.69, 29.63, 29.5, 29.39, 29.31, 29.2, 28.9, 27.2, 22.7, 14.1; HRMS (m/z) calcd for $\mathrm{C}_{26} \mathrm{H}_{42} \mathrm{NaO}_{4}$ $[\mathrm{M}+\mathrm{Na}]^{+}:$441.2981; found: $441.2966(-3.4 \mathrm{ppm})$. 


\section{L-ornithine, $\mathbf{N}^{5}$-octadecanoylamide- $\mathrm{N}^{2}$-(2-benzyloxycarbonyl)octadecanoylamide (12)}

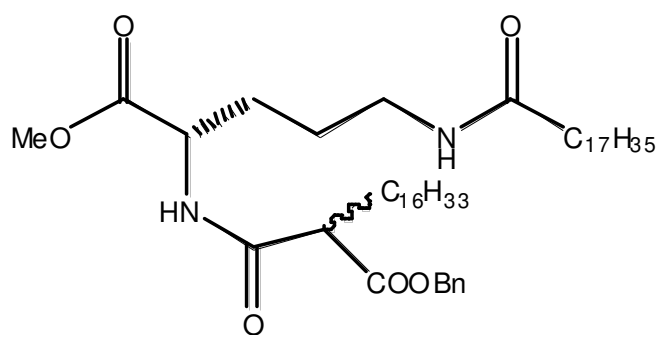

12

To a solution of compound $\mathbf{1 0}(0.20 \mathrm{~g}, 0.48 \mathrm{mmol})$ in $\mathrm{CH}_{2} \mathrm{Cl}_{2}(20 \mathrm{ml})$ was sequentially added $N, N^{\prime}$-dicyclohexylcarbodiimide $(0.12 \mathrm{~g}, 0.58 \mathrm{mmol})$ and monoester $11(0.20 \mathrm{~g}, 0.48 \mathrm{mmol})$. The reaction mixture was refluxed for $4 \mathrm{~h}$, cooled to rt, and then filtered. The filtrate was dried over anhydrous $\mathrm{Na}_{2} \mathrm{SO}_{4}$, and then refiltered before being concentrated in vacuo. Flash chromatography (Hexane/EtOAc, 60:40) afforded 12 as a white solid (0.28 g, 72\%), R 0.4 (Hexane/EtOAc 50/50). Mp 100-101 C; IR 3304, 2916, 2849, 1736, 1639, 1545, 1272, 1236, 720, $695 \mathrm{~cm}^{-1} ;{ }^{1} \mathrm{H}$ NMR: $\delta 7.37(\mathrm{~m}, 5 \mathrm{H}), 7.17(\mathrm{~d}, \mathrm{~J}=7.5 \mathrm{~Hz}, 0.5 \mathrm{H}), 7.13(\mathrm{~d}, \mathrm{~J}=7.8 \mathrm{~Hz}, 0.5 \mathrm{H}$, isomer), $5.72(\mathrm{t}, \mathrm{J}=6.3 \mathrm{~Hz}, 1 \mathrm{H}), 5.20(\mathrm{~m}, 2 \mathrm{H}), 4.58(\mathrm{~m}, 1 \mathrm{H}), 3.75(\mathrm{~s}, 1.5 \mathrm{H}), 3.74(\mathrm{~s}, 1.5 \mathrm{H}$, isomer), $3.31(\mathrm{dd}, \mathrm{J}=7.1,14.3 \mathrm{~Hz}, 1 \mathrm{H}), 3.24(\mathrm{~m}, 2 \mathrm{H}), 2.15(\mathrm{~m}, 2 \mathrm{H}), 1.86(\mathrm{~m}, 4 \mathrm{H}), 1.65-1.25(60 \mathrm{H}), 0.89$ (t, J=6.9 Hz, 6H); ${ }^{13} \mathrm{C}$ NMR 173.38, 173.31(isomer), 172.3, 172.2(isomer), 171.7, 171.4(isomer), 168.4, 168.3(isomer), 135.32, 135.29(isomer), 128.6, 128.5, 128.4, 67.2, 52.95, 52.86(isomer), 52.51, 52.48(isomer), 51.93, 51.91(isomer), 38.6, 26.8, 31.9, 30.9, 30.5, 29.71, 29.66, 29.5, $29.40,29.37,29.22,29.17,27.25,27.21,25.8,25.4,22.7,14.1 ; H R M S(\mathrm{~m} / \mathrm{z}$ calcd for $\mathrm{C}_{50} \mathrm{H}_{88} \mathrm{~N}_{2} \mathrm{NaO}_{6}$ ) [M+Na] $]^{+}$: 835.6540; found: 835.6533 (-0.8 ppm).

3-Hexadecyl-5-(3-aminopropyl)-pyrrolidine-2,4-one, octadecanoyl amide (8) was prepared using a modification of a procedure reported for other tetramic acids. ${ }^{8}$ 


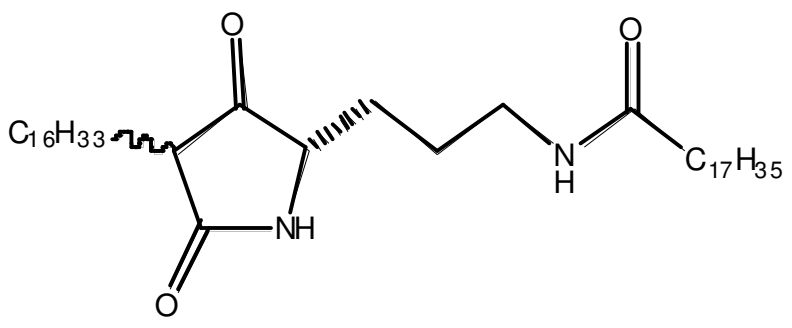

8

To a 100ml RB flast was added $\mathrm{NaH}$ (60\% dispersion in mineral oil, $13 \mathrm{mg}, 0.37 \mathrm{mmol})$. The slurry was washed by pentane, after which compound $12(81 \mathrm{mg}, 0.10 \mathrm{mmol})$ was added in THF $(10 \mathrm{ml})$. The reaction mixture was refluxed for $6 \mathrm{~h}$ and then cooled to rt. After removal of solvent in vacuo, the residue was suspended in water $(15 \mathrm{ml})$ and the solution acidified to $\mathrm{pH} 2$ with $3 \mathrm{M}$ $\mathrm{HCl}$. The combined $\mathrm{CH}_{2} \mathrm{Cl}_{2}$ extracts $(10 \mathrm{ml} \times 3)$ were dried over anhydrous $\mathrm{Na}_{2} \mathrm{SO}_{4}$ and the filtrate concentrated in vacuo. Flash chromatography $\left(\mathrm{CH}_{2} \mathrm{Cl}_{2} / \mathrm{MeOH}, 95: 5\right)$ afforded $\mathbf{8}$ as a white solid (48 mg, 74\%). $\mathrm{R}_{\mathrm{f}} 0.5\left(\mathrm{CH}_{2} \mathrm{Cl}_{2} / \mathrm{MeOH}\right.$ 90/10). Mp 108-109 ${ }^{\circ} \mathrm{C}$. IR 2916, 2848, 1686, 1639, 1467, $720 \mathrm{~cm}^{-1} ;{ }^{1} \mathrm{H}$ NMR: $\delta 6.94(\mathrm{~d}, \mathrm{~J}=3.9 \mathrm{~Hz}, 0.5 \mathrm{H}), 6.88(\mathrm{~d}, \mathrm{~J}=8.4 \mathrm{~Hz}, 0.5 \mathrm{H}$, isomer), $5.60(\mathrm{t}, \mathrm{J}=5.4 \mathrm{~Hz}, 1 \mathrm{H}), 4.01(\mathrm{t}, \mathrm{J}=6.7 \mathrm{~Hz}, 0.5 \mathrm{H}), 3.92(\mathrm{t}, \mathrm{J}=5.4 \mathrm{~Hz}, 0.5 \mathrm{H}$, isomer), $3.29(\mathrm{~m}, 2 \mathrm{H})$, $2.83(\mathrm{t}, \mathrm{J}=5.8 \mathrm{~Hz}, 0.5 \mathrm{H}), 2.76(\mathrm{t}, \mathrm{J}=5.8 \mathrm{~Hz}, 0.5 \mathrm{H}$, isomer), 2.17 (t, J= $7.6 \mathrm{~Hz}, 2 \mathrm{H}), 1.91-1.56(8 \mathrm{H})$, 1.47-1.20 (56H), 0.90 (t, J=6.6 Hz, 6H); ${ }^{13} \mathrm{C}$ NMR (150 MHz): 211.1, 210.7 (isomer), 174.2, 173.9 (isomer), 173.6, 62.3, 61.9(isomer), 49.7, 49.1(isomer), 38.5, 36.8, 31.9, 29.71, 29.67, $29.58,29.52,29.37,29.34,29.31,28.7,27.2,26.6,26.5,26.20,25.9,25.8,25.5,22.7,14.1$; HRMS (m/z) calcd for $\mathrm{C}_{41} \mathrm{H}_{78} \mathrm{~N}_{2} \mathrm{NaO}_{3}{ }^{+}[\mathrm{M}+\mathrm{Na}]^{+}$: 669.5910; found: 669.5935 (3.7 ppm).

\section{References}


1. Yu, F., Zaleta-Rivera, K., Zhu, X., Huffman, J., Millet, J.C., Harris, S.D., Yuen, G., Li, X.C., and Du, L. (2007). Structure and biosynthesis of heat-stable antifungal factor (HSAF), a broad-spectrum antimycotic with a novel mode of action. Antimicrob. Agents Chemother. 51, 64-72.

2. Stachelhaus, T., and Marahiel, M.A. (1995). Modular structure of peptide synthetases revealed by dissection of the multifunctional enzyme GrsA. J. Biol. Chem. 270, 61636169.

3. Gerber, R., Lou, L., and Du L. (2009). A PLP-dependent polyketide chain releasing mechanism in the biosynthesis of mycotoxin fumonisins in Fusarium verticillioides. $J$. Am. Chem. Soc. 131, 3148-3149

4. Sanchez, C., Du, L., Edwards, D.J., Toney, M.D., and Shen, B. (2001). Cloning and characterization of a phosphopantetheinyl transferase from Streptomyces verticillus ATCC15003, the producer of the hybrid peptide-polyketide antitumor drug bleomycin. Chem. Biol. 8, 725-738.

5. Dent, W. H., Erickson, W. R., Fields S. C.; Parker, M. H.; Tromiczak, E. G. (2002). 9BBN: An Amino Acid Protecting Group for Functionalization of Amino Acid Side Chains in Organic Solvents. Org. Lett. 4, 1249-1251.

6. Royles, B. J. L. (1995). Naturally Occurring Tetramic Acids: Structure, Isolation, and Synthesis. Chem. Rev. 95, 1981-2001.

7 Poncet, J.; Jouin, P.; Castro, B.; Nicolas, L.; Boutar, M.; Gaudemer, A. (1990). Tetramic Acid Chemistry. Part I. Reinvestigation of Racemisation during the Synthesis of Tetramic Acids via Dieckmann Cyclisation. Perkins 1, 611-616. 
8 Page, P. C. B.; Hamzah, A. S.; Leach, D. C.; Allin, S. M.; Andrews, D.M.; Rassias, G. A. (2003). Short and Versatile Route to a Key Intermediate for Lactacystin Synthesis. Org. Lett. 5, 353-355.

9 Mulholland, T. P. C.; Foster, R.; Haydock, D. B. (1972). Synthesis of Pyrrolidine-2,4diones (Tetramic acids) and Some Derivatives. Perkins 1, 2121-2128. 


\section{Supporting Information (Part 2 of 2)}

\section{Biosynthesis of HSAF, a Tetramic Acid-containing Macrolactam from Lysobacter enzymogenes}

Lili Lou, Guoliang Qian, Yunxuan Xie, Jiliang Hang, Haotong Chen, Kathia Zaleta-Rivera, Yaoyao Li, Yuemao Shen, Patrick H Dussault, Fengquan Liu and Liangcheng Du

${ }^{1} \mathrm{H}$ and ${ }^{13} \mathrm{C}$ NMR spectra of the chemically synthesized tetramic acid (8) and the synthetic precursors

$\mathrm{N}_{5}$-octadecanoyl-L-ornithine, 9-borabicyclononane complex

$L$-ornithine, $\mathrm{N}_{5}$-octadecanoylamide, methyl ester (10)

2-(Benzyloxycarbonyl)octadecanoic acid, benzyl ester p 6-7

2-(Benzyloxycarbonyl)octadecanoic acid. (11)

p 8-9

$L$-ornithine, $\mathrm{N}_{5}$-octadecanoylamide- $\mathrm{N}_{2}$-(2-benzyloxycarbonyl)octadecanoylamide (12) p 10-11

3-Hexadecyl-5-(3-aminopropyl)-pyrrolidine-2,4-one, octadecanoyl amide (8)

p $12-13$ 


\section{Spin Works 3: 1D Proton NMR}

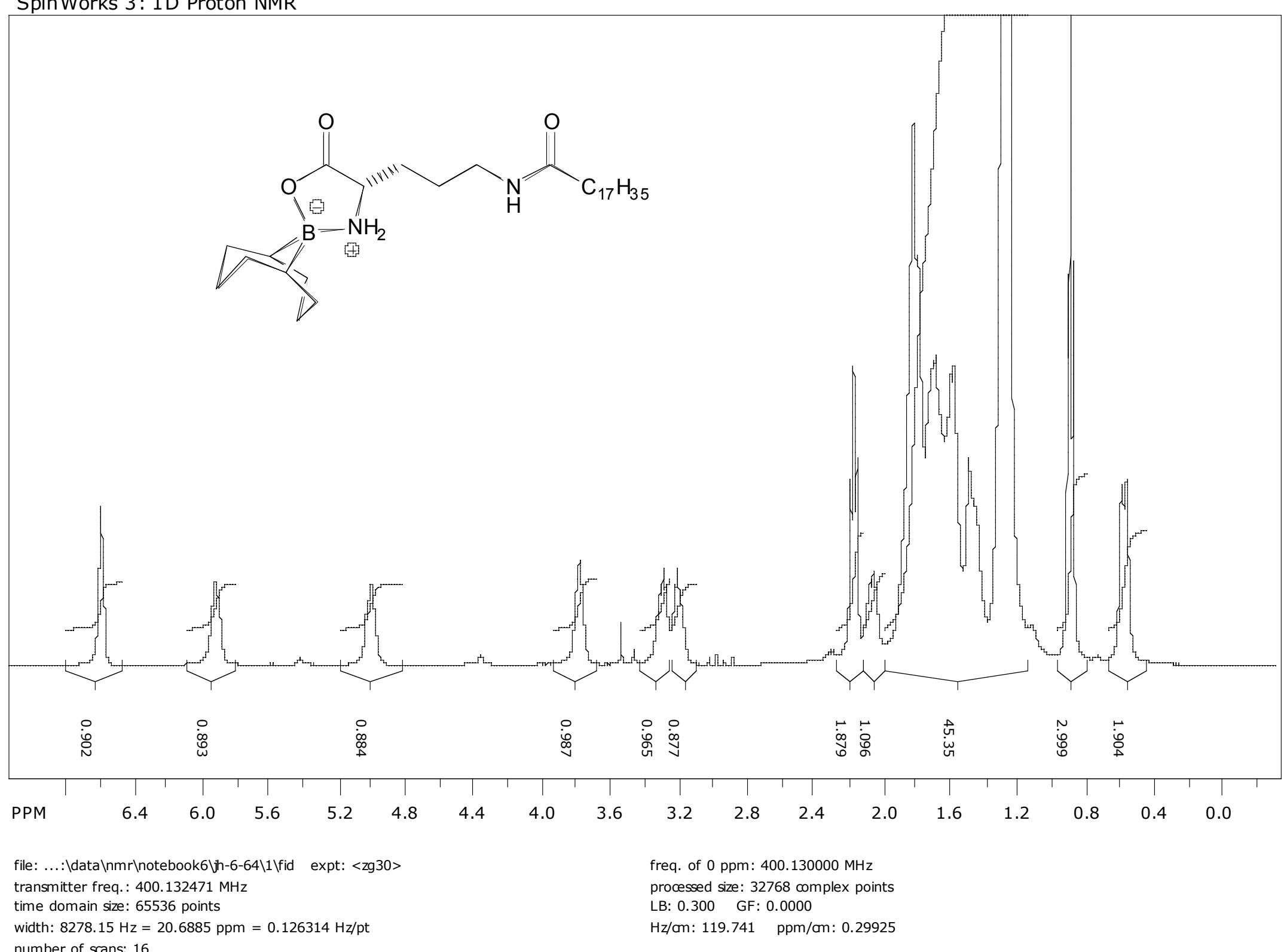


Spin Works 3: 13C

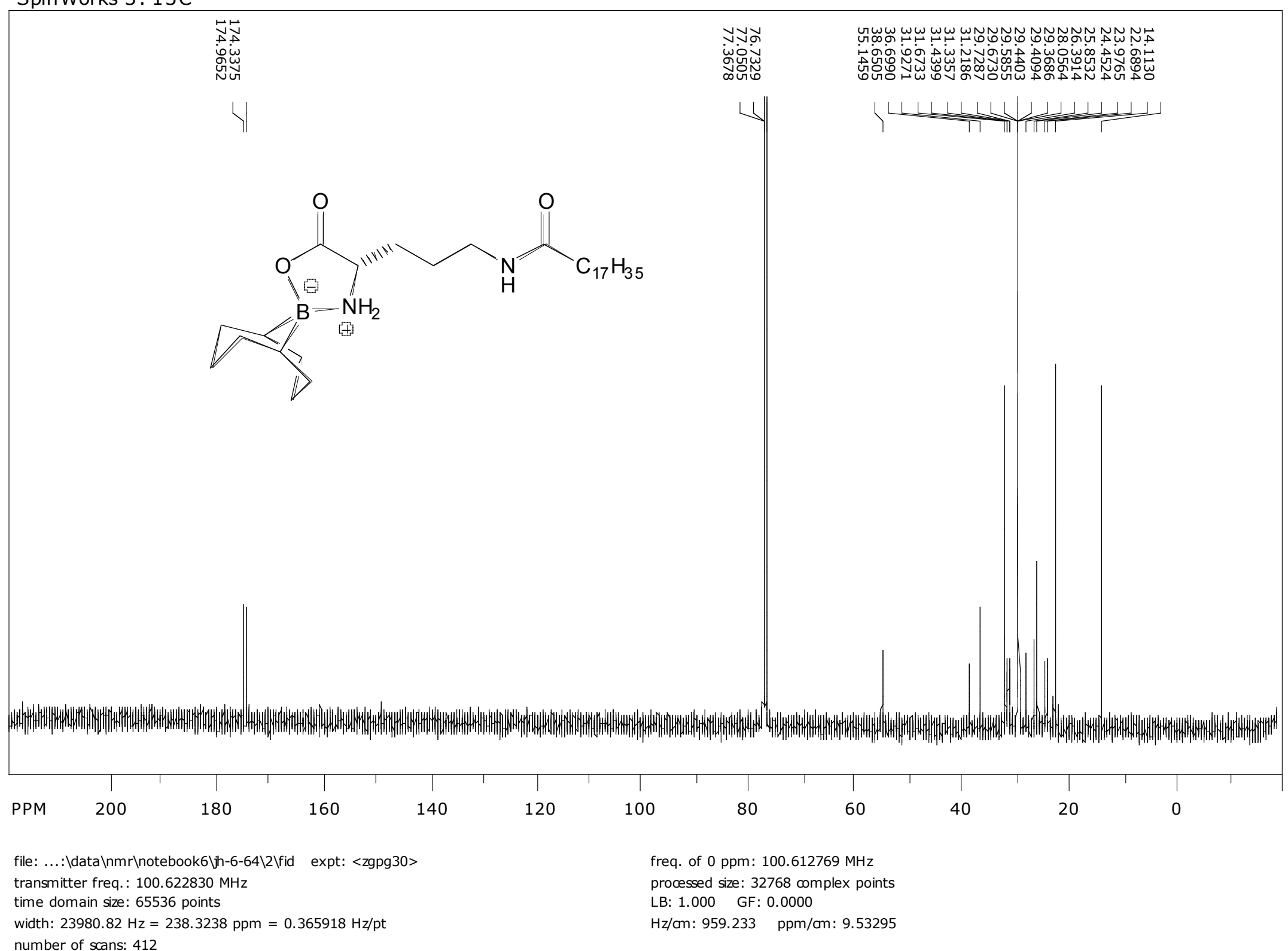




\section{Spin Works 3: 1D Proton NMR}

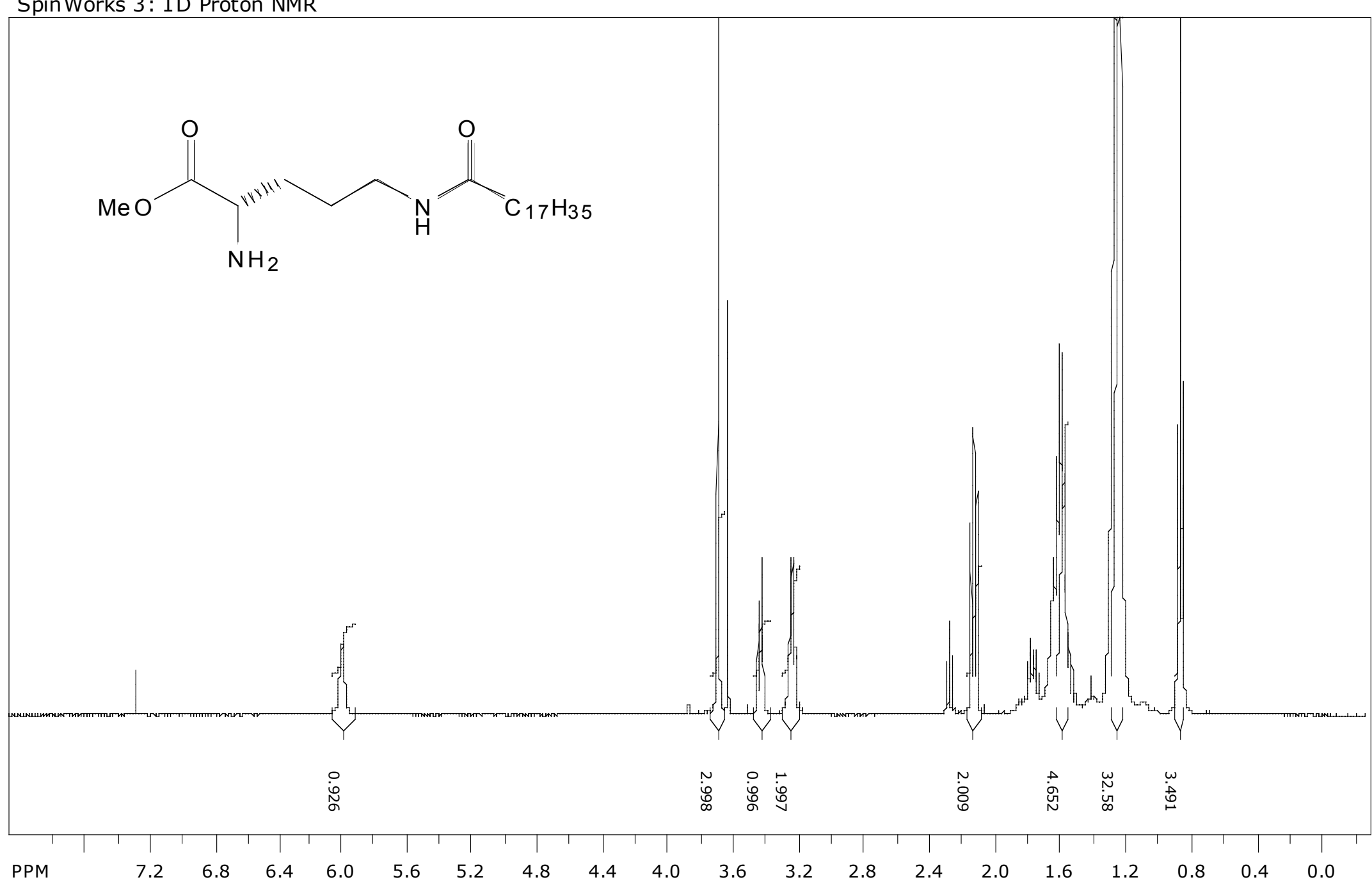

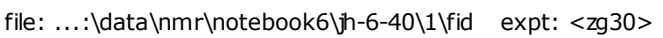

transmitter freq.: $400.132471 \mathrm{MHz}$

time domain size: 65536 points

freq. of $0 \mathrm{ppm}: 400.130000 \mathrm{MHz}$

processed size: 32768 complex points

LB: 0.300 GF: 0.0000

$\mathrm{Hz} / \mathrm{am}: 133.658 \mathrm{ppm} / \mathrm{cm}: 0.33403$

number of scans: 16 
Spin Works 3: 13C

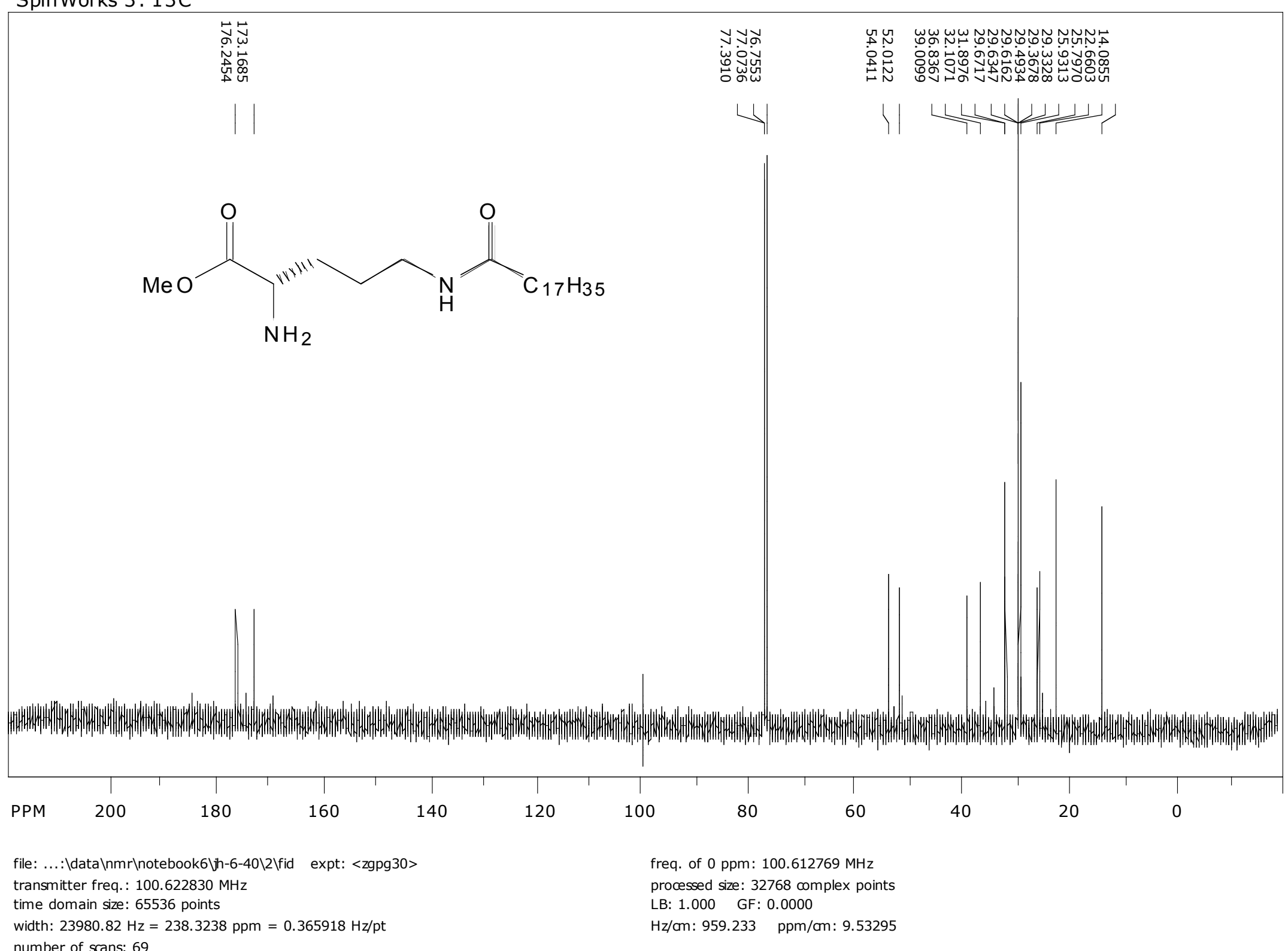




\section{Spin Works 3: 1D Proton NMR}

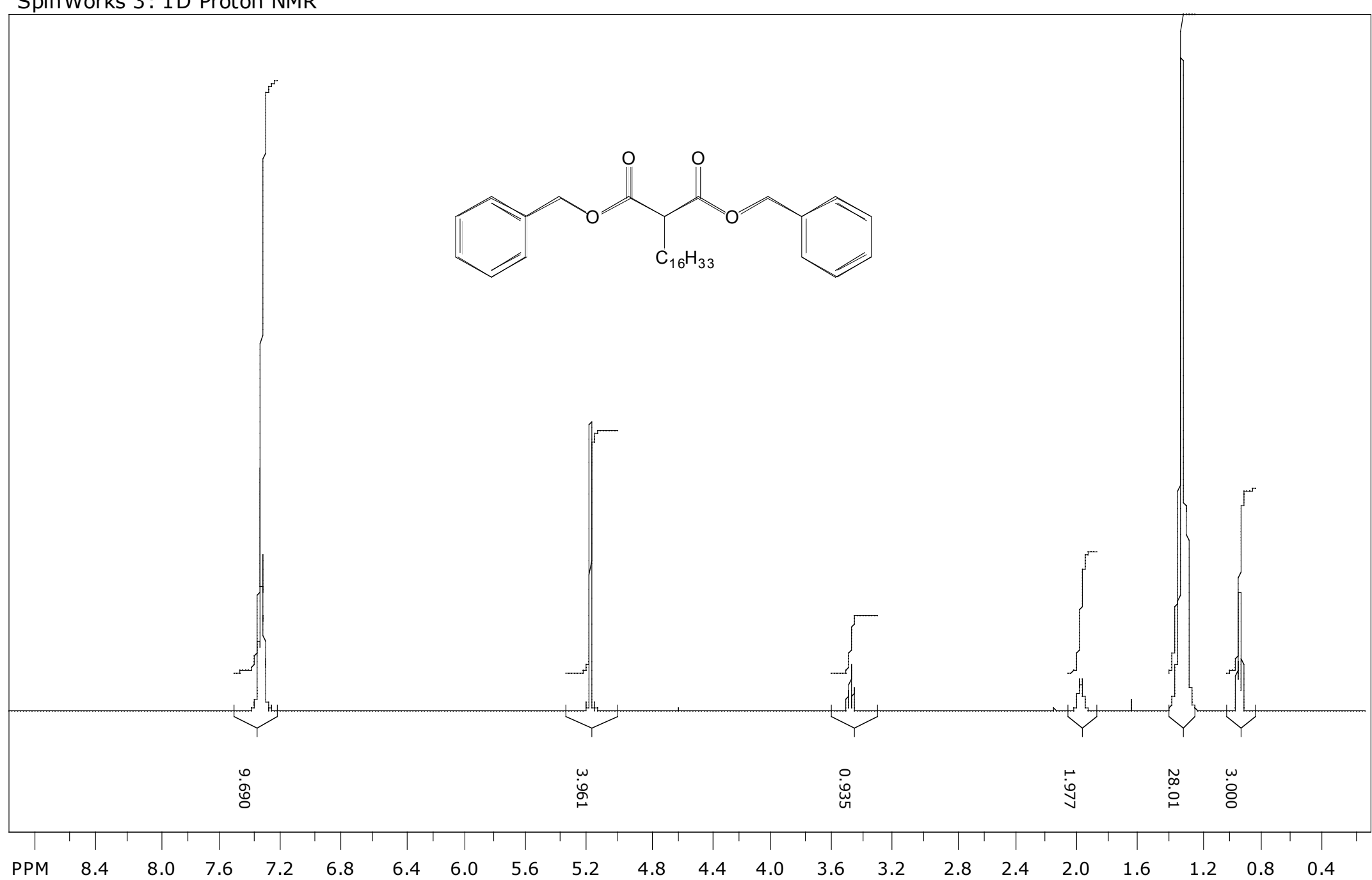

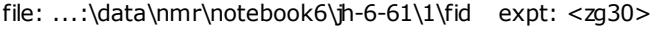

transmitter freq.: $400.132471 \mathrm{MHz}$

time domain size: 65536 points

width: $8278.15 \mathrm{~Hz}=20.6885 \mathrm{ppm}=0.126314 \mathrm{~Hz} / \mathrm{pt}$

number of scans: 16 freq. of $0 \mathrm{ppm}: 400.130000 \mathrm{MHz}$

processed size: 32768 complex points

LB: 0.300 GF: 0.0000

$\mathrm{Hz} / \mathrm{am}: 142.586 \mathrm{ppm} / \mathrm{cm}: 0.35635$ 
Spin Works 3: $13 \mathrm{C}$

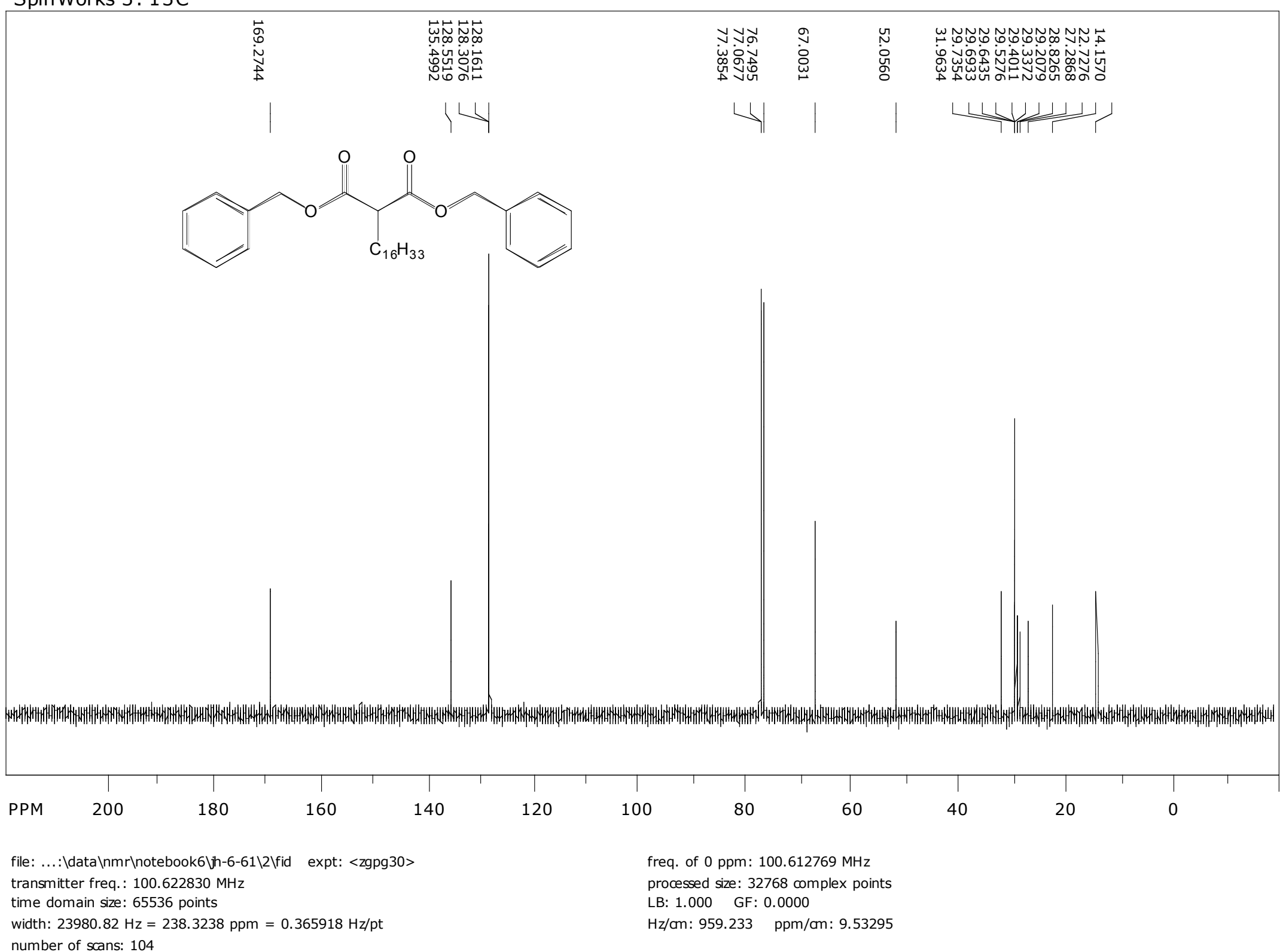




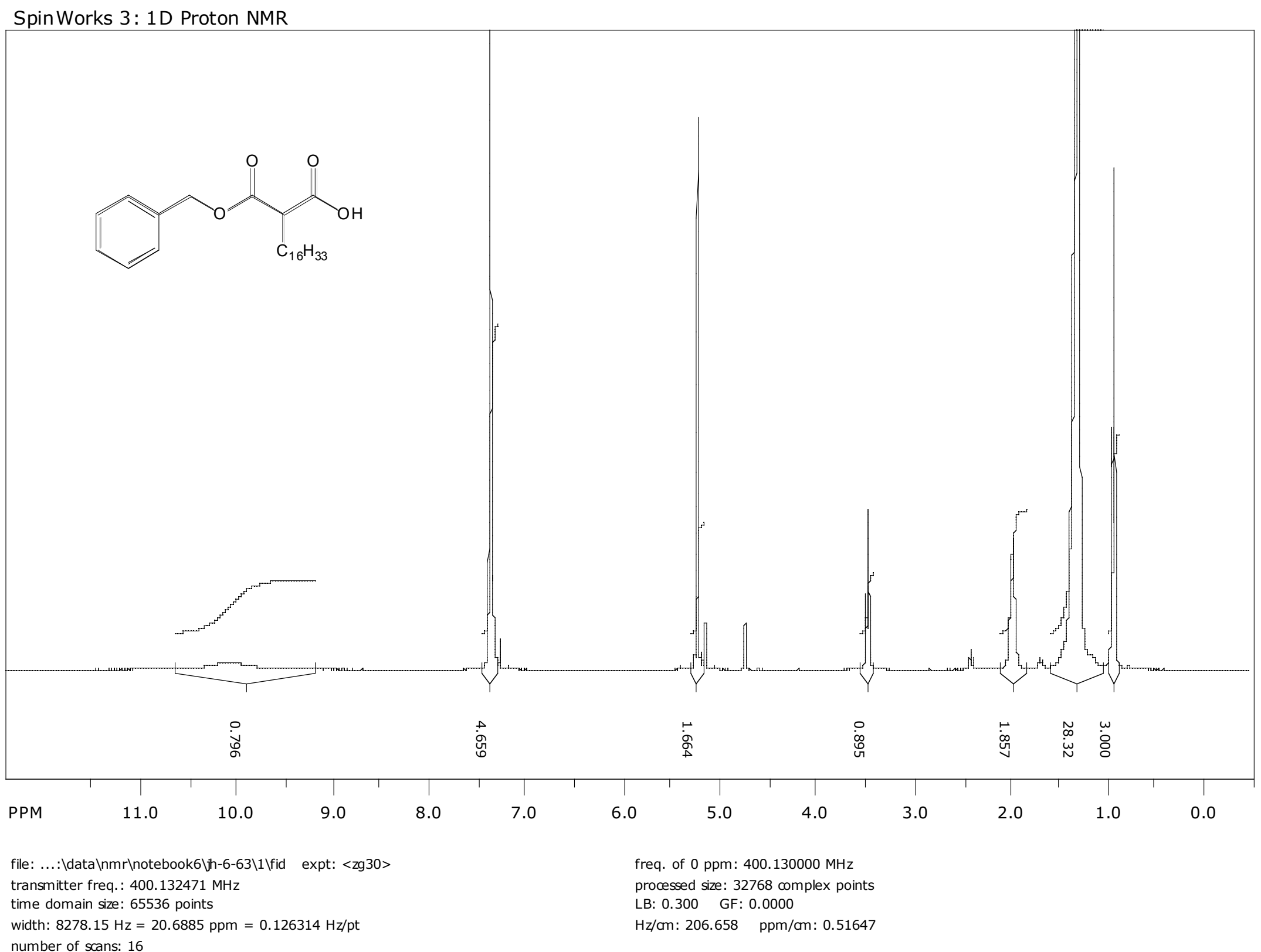


Spin Works 3: 13C

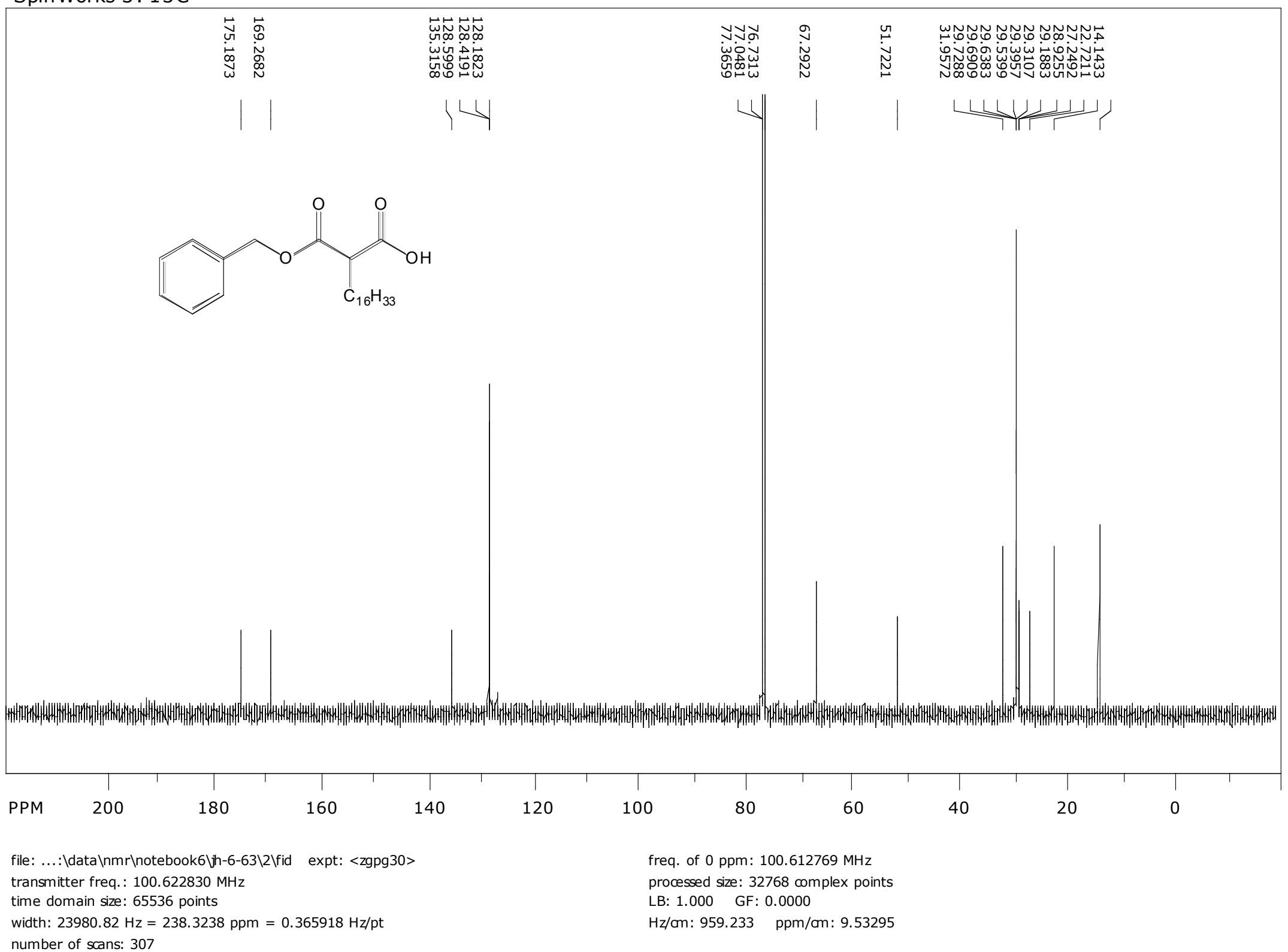




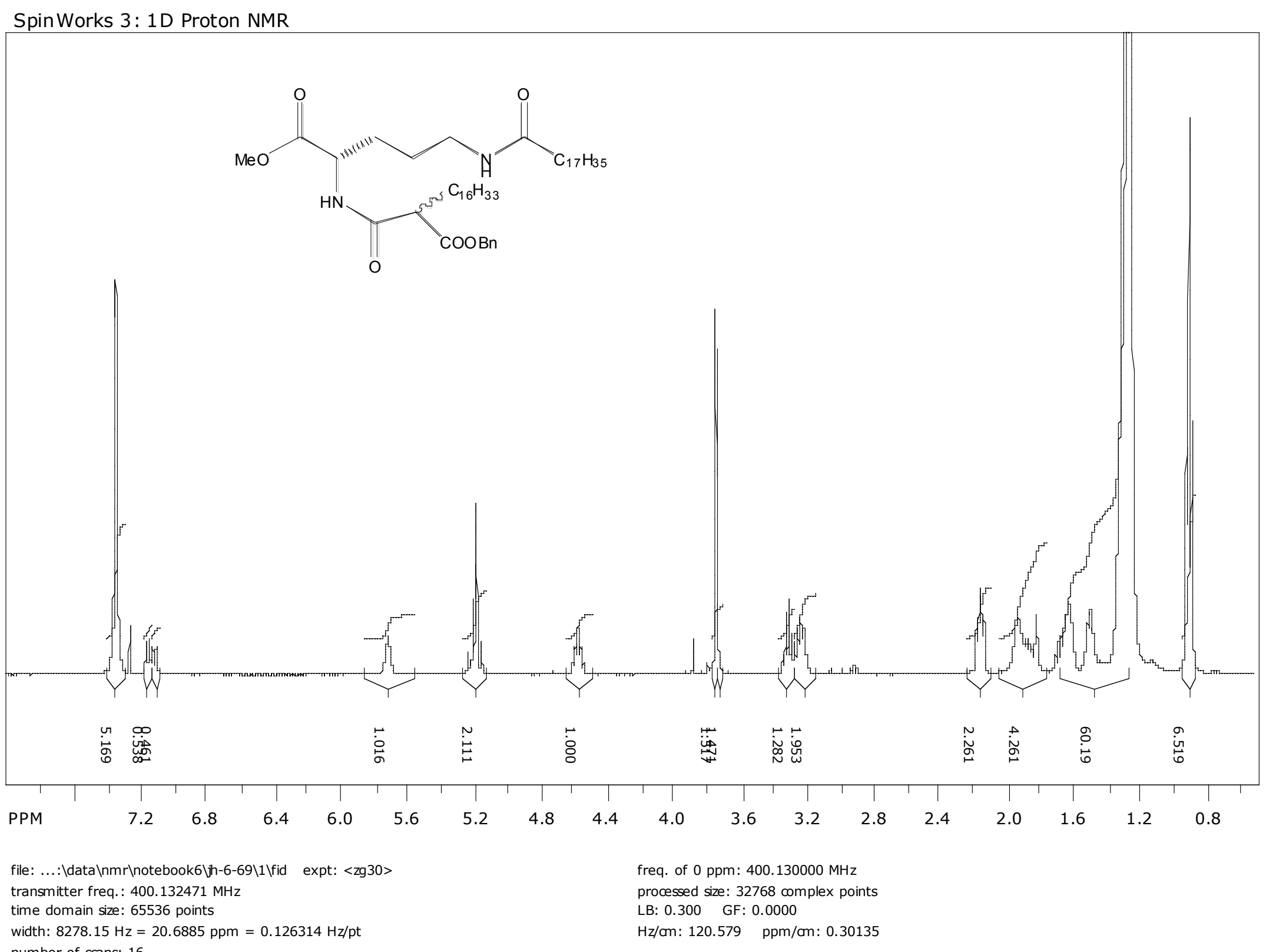


Spin Works 3: 13C

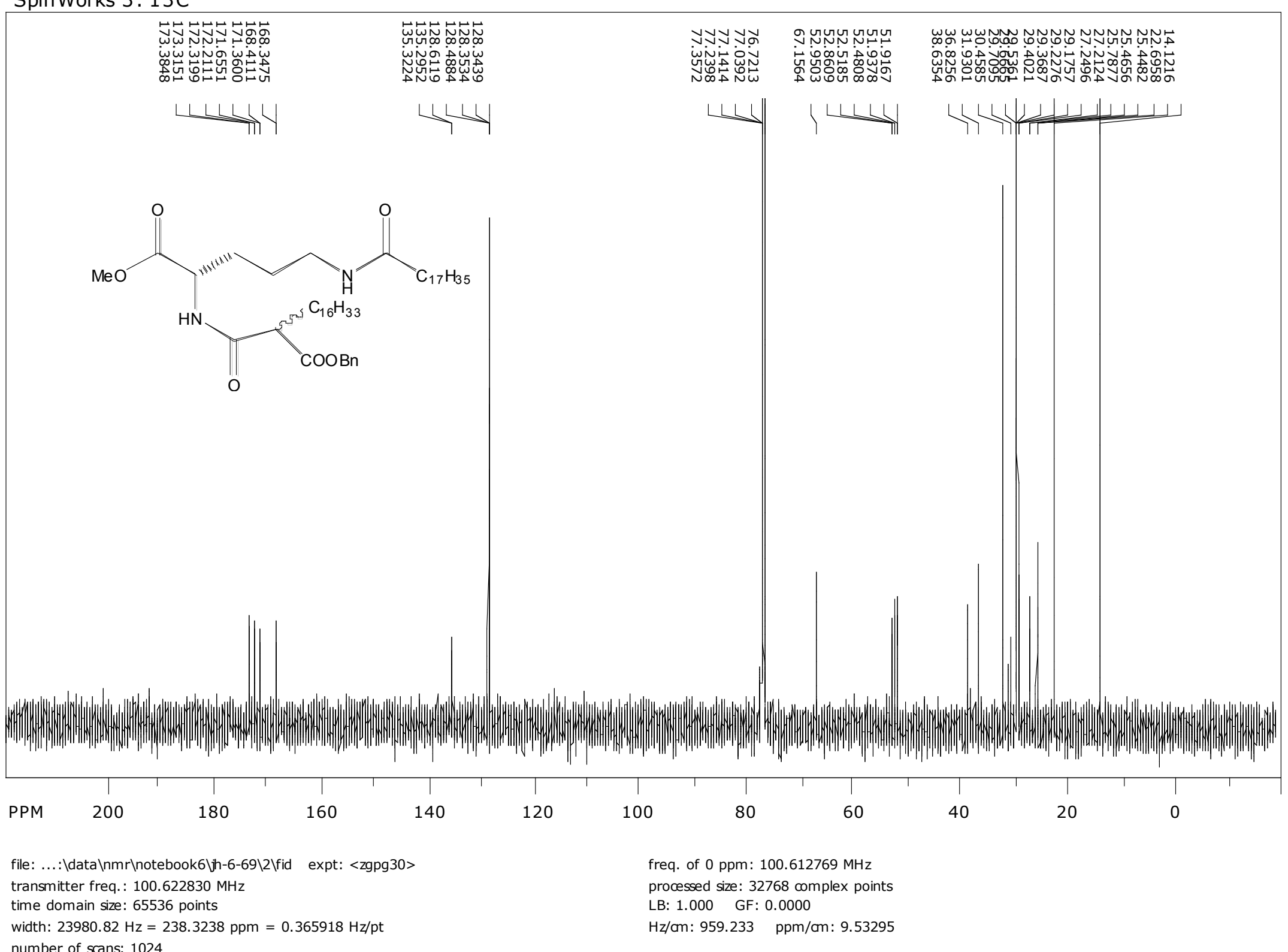




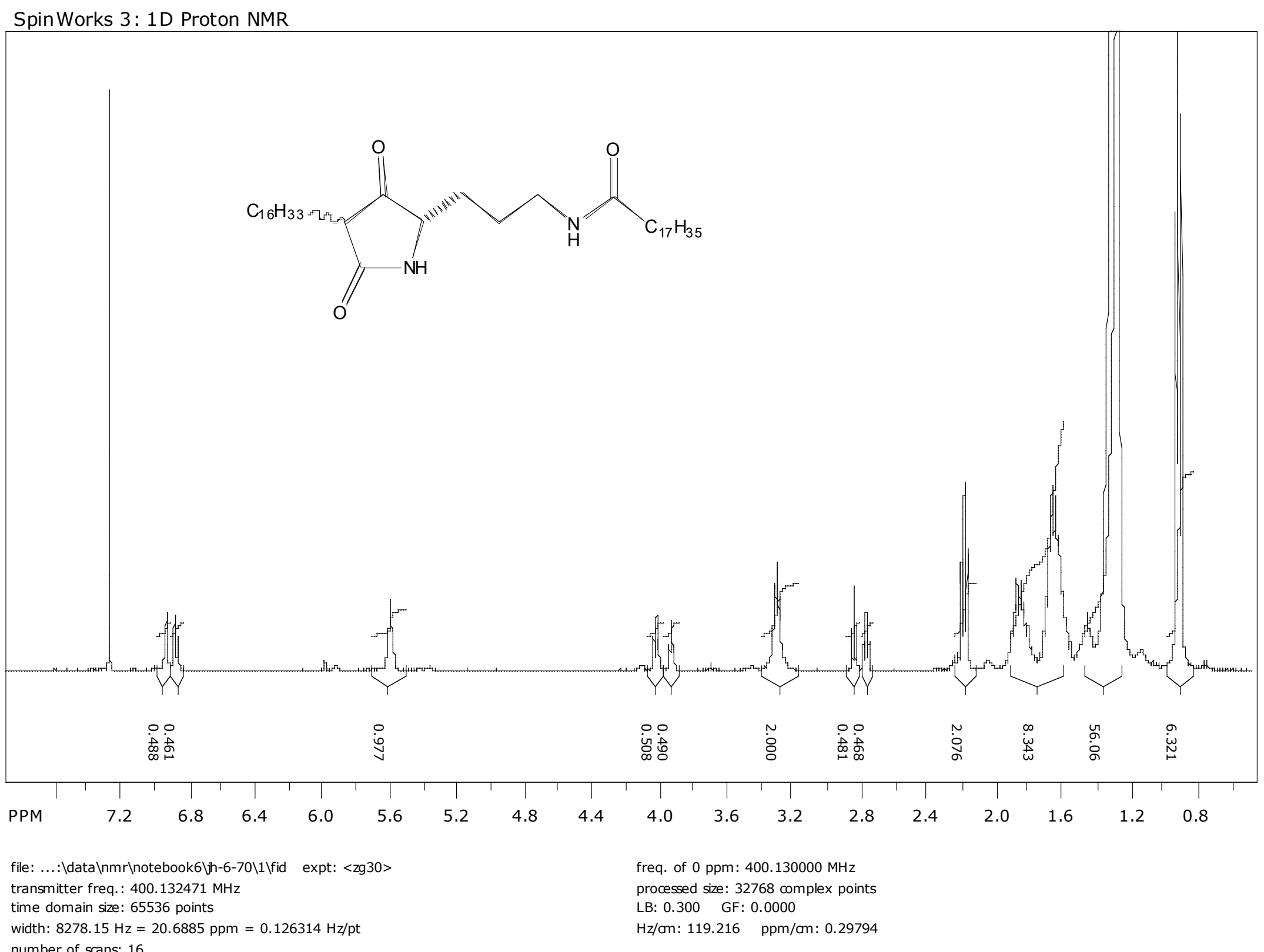




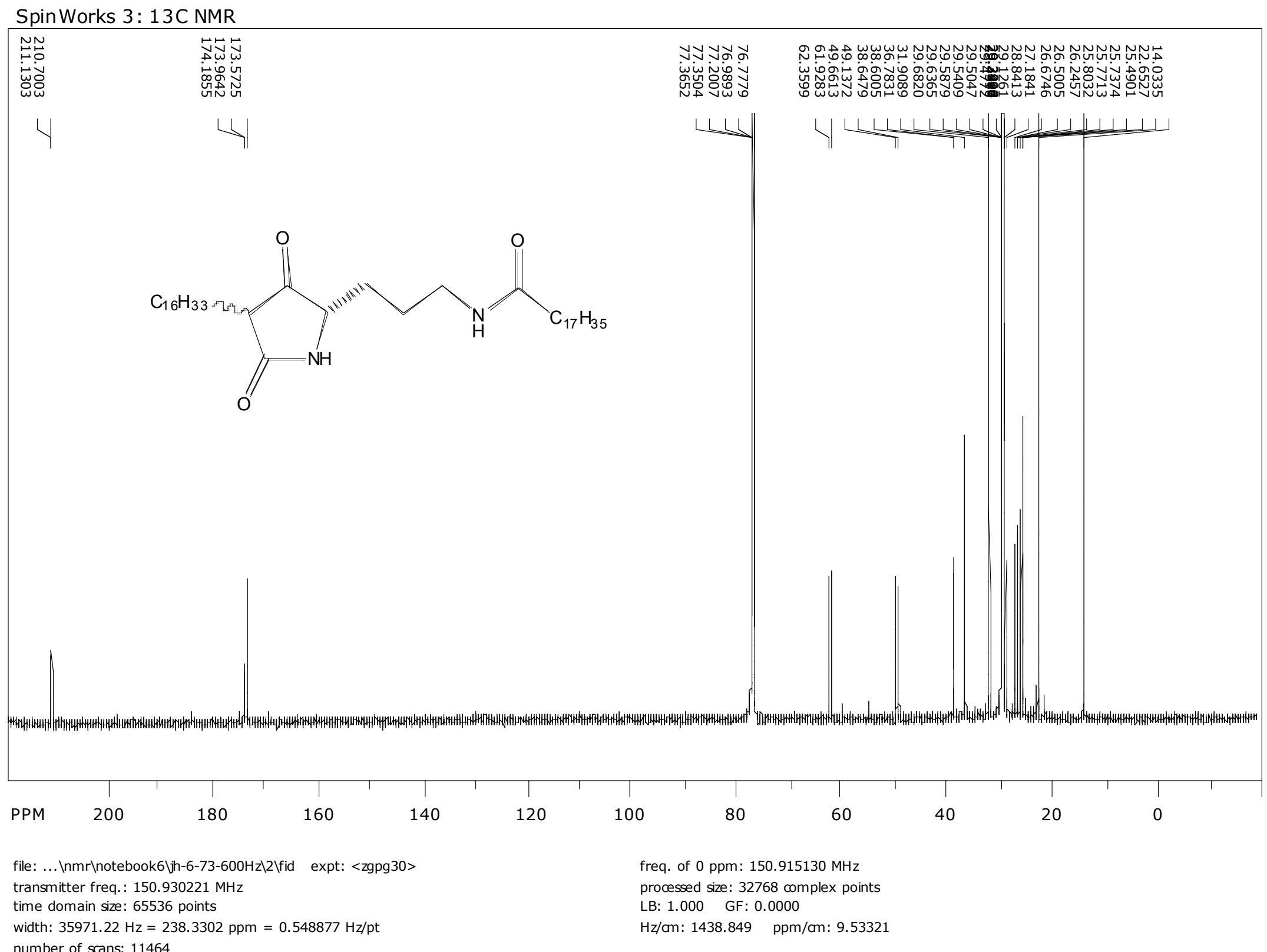

